\title{
Myotonic Dystrophy Type 1 (DM1): From the Genetics to Molecular Mechanisms
}

\author{
Jonathan J. Magaña ${ }^{1}$ and Bulmaro Cisneros ${ }^{2}$ \\ ${ }^{1}$ Genetics Department, Genomic Medicine Laboratory, National Rehabilitation Institute; \\ ${ }^{2}$ Genetics and Molecular Biology Department, CINVESTAV-IPN, \\ Mexico
}

\section{Introduction}

For a long time, the human genome was considered an intrinsically stable entity; however, it is currently known that our human genome contains many unstable elements consisting of tandem repeat elements, mainly Short tandem repeats (STR), also known as microsatellites or Simple sequence repeats (SSR) (Ellegren, 2000). These sequences involve a repetitive unit of 1-6 bp, forming series with lengths from two to several thousand nucleotides. STR are widely found in pro- and eukaryotes, including humans. They appear scattered more or less evenly throughout the human genome, accounting for ca. 3\% of the entire genome (Sharma et al., 2007). STR are polymorphic but stable in general population; however, repeats can become unstable during DNA replication, resulting in mitotic or meiotic contractions or expansions. STR instability is an important and unique form of mutation that is linked to $>40$ neurological, neurodegenerative, and neuromuscular disorders (Pearson et al., 2005). In particular, abnormal expansion of trinucleotide repeats (CTG)n, (CGG)n, (CCG)n, (GAA)n, and (CAG)n have been associated with different diseases such as fragile $X$ syndrome, Huntington disease (HD), Dentatorubral-pallidoluysian atrophy (DRPLA), Friedreich ataxia (FA), diverse Spinocerebellar ataxias (SCA), and Myotonic dystrophy type 1 (DM1).

In 1909, Hans Gustav Wilhelm Steinert, as well as Frederick Eustace Batten and H.P. Gibb, described for the first time a muscular dystrophy characterized by progressive muscle weakness and myotonia (involuntary muscle contraction and delayed relaxation due to muscle hyperexcitability) denominated Myotonic dystrophy or Steinert disease (Schara and Schoser, 2006). Currently, two distinct mutations are known that lead to the clinical syndrome of DM: Myotonic dystrophy type 1 (DM1), caused by expansion of CTG repeats within the $3^{\prime}$ untranslated region of the Dystrophia myotonica-protein-kinase gene (DMPK) on chromosome 19 (Brook et al., 1992), and Myotonic dystrophy type 2, due to expansion of CCTG repeats in intron 1 of the Zinc finger protein gene (ZNF9) on chromosome 3 (Liquori et al., 2001). DM1 is an autosomal dominant inherited disease that represents the most common form of muscular dystrophy in adults with a prevalence of 1 in 8,000 individuals worldwide. In addition to muscular pathology, DM1 symptomatology includes cardiac conduction defects, insulin resistance, and cognitive alterations in the congenital form of the disease (Harper et al., 2002). For some time, it was difficult to decipher the manner in which a repeat expansion in the $D M P K$ gene causes a multisystemic disease with dominant 
inheritance pattern. However, the fact that such a mutated region is transcribed but untranslated implies that mutant RNA might play a significant role in the disease process. Supporting this hypothesis, growing pieces of evidence obtained over the past 10 years have established that DM1- mutant RNA accumulates in the nuclei, disturbing RNA splicing and gene expression through sequestering of splicing and transcription factors, respectively (Day \& Ranum, 2005; Ebralidze et al., 2004).

In this chapter, the clinical features of DM1 and the scientific pathway that allowed elucidation of the molecular basis of DM1 pathogenesis are described in detail. In addition, a discussion of recent developments in molecular therapy for fighting DM1 is provided.

\section{Clinical aspects}

DM1 is one of the most frequent genetic diseases and is also one of the most variable disorders. Symptoms and severity vary greatly among family members and between generations. Patients may even remain undiagnosed or be misdiagnosed for years, if not recognized as being a member of a family with DM1. However, within the broad spectrum of clinical symptoms, there are some distinct phenotypes according to age-of-onset and number of CTG repeats.

\subsection{Multisystemic symptomatology}

Clinical manifestations of DM1 involve a great number of organs and tissues and vary from the pre-/post-natal period to adulthood. Skeletal muscle pathology is the most characteristic feature of DM1. Impaired muscle relaxation from myotonia can lead to stiffness and cramping, especially in distal muscles of the hands, but it is rarely a significant complaint registered by patients. Muscle weakness and wasting start distally on distal limbs, neck, and face, and progress proximally over time, often leading to severe disability as the disease progresses (Schara and Schoser, 2006). Respiratory muscle involvement is common, and respiratory failure, either from the primary muscle process or from cardiopulmonary involvement, is a significant contributor to patient mortality (Machuca-Tzili L et al., 2005). A less well-defined but important disease feature is its effect on the Central nervous system (CNS) and cognition, which can be manifested by psychological dysfunction, mental retardation, excessive diurnal sleepiness, and neuropathological abnormalities (Rubinsztein et al., 1998; Laberge et al., 2009). Recent work has demonstrated global deficits with neuropsychological testing, as well as radiographic changes in the brains of affected individuals, including increased white matter lesion burden, decreased gray matter mass (especially in hippocampal and thalamic regions), and hypometabolism in frontal lobes (Di Constanzo et al., 2002a, 2008b; Ono et al., 2001). Alterations of personality associated with DM1 include avoidant personality, obsessive-compulsive, passive-aggressive, and schizotypic traits, whose occurrence is not attributable to the patients' disabling condition (Delaporte 1998; Winblad et al., 2005). Other studies have found severe impairment in all measurements of general intelligence and verbal fluency (Rubinsztein et al., 1997).

In addition to the effects on the CNS, $90 \%$ of patients with DM1 could develop cardiac abnormalities at some point of disease development. First-degree atrioventricular block and intraventricular conduction disorders are observed commonly in subjects with DM1, followed by lethal arrhythmias and occasional signs of cardiomyopathy. Echocardiograph 
findings include prolapsed mitral valve, depressed left ventricular systolic function, reductions in ejections fraction, fractional shortening, and reduced stroke volume (Melacini et al., 1995). In fact, sudden cardiac failure is one of the main causes of death in these patients and occurs with a high incidence of $30 \%$. In the ocular system of these patients, the incidence of lens opacities is very high and manifests as posterior subcapsular, iridescent, multicolored cataracts. Moreover, changes in the Retinal pigment epithelium (RPE), known as Pigment pattern dystrophy (PPD), could be present in the peripheral retina or in macula, mimicking retinitis pigmentosa (Grover et al., 2002; Kim et al., 2009; Louprasong et al., 2010). The ocular muscles are also affected, resulting in external ophthalmoplegia, bilateral motility disturbance, obicularis oculi and levator muscle weakness, and ptosis. Other ocular defects include decreased vision and decreased intraocular pressure (Rosa et al., 2011). Patients with DM1 could also present endocrine defects including insulin resistance and gonadal atrophy (García de Andoin et al., 2005; Matsumura et al., 2009), as well as smooth muscle dysfunction, the clinical effects of which are observed mainly in the gastrointestinal tract and result in disordered esophageal and gastric peristalsis (Machuca-Tzili L et al., 2005).

\subsection{Adult-onset and congenital myotonic dystrophy}

Based on the clinical findings as well as age-at-onset and disease course, DM1 has been categorized into two main and somewhat overlapping phenotypes: adult-onset, and Congenital myotonic dystrophy (CDM). A rough correlation exists between CTG repeat tract size and these two main forms of DM1 (see Genetics of DM1 section).

Adult-onset presents the classical manifestations of DM1, including myotonia, muscle weakness, cardiac rhythm abnormalities, and endocrine and gonadal abnormalities. The disease progresses insidiously but can become debilitating in the fifth and sixth decades of life. Some authors have classified adult-onset in into two subtypes (mild and classic DM1) according to age-at-onset. Mild DM1 could be asymptomatic or may have only cataracts, mild myotonia, and/or diabetes mellitus. It usually begins in old age and patients may have fully active lives and normal or minimally shortened life span. Classic DM1 is the most common presentation of DM1. The predominant symptom is distal muscle weakness, leading to foot drop disturbance and difficulty with performing tasks requiring fine manual dexterity. Myotonia may interfere with daily activities and the typical face of the patients is principally caused by weakness of facial and levator palpebrae muscles; however, expressivity can be variable, and the presentation could include one or several DM1 features, including cardiac abnormalities, respiratory failure, endocrine abnormalities, smooth muscle dysfunction, cataracts, and hypersomnolence. Age-at-onset for classic DM1 is typically in the third of fourth decades of life, and presents uncommonly after 40 years of age. Nevertheless, in some cases, the pathology begins in the childhood stage (first decade of life), exhibiting evident facial weakness and myotonia, and more severe evolution characterized by low IQ, psychiatric alteration, and early cardiac abnormalities.

CDM is the most severe form of the disease and is usually inherited maternally (Harley et al., 1993). Prenatal stage is characterized by polyhydramnios and reduced fetal movement, all caused by muscle action failure. The main features of congenital DM1 include generalized hypotonia and weakness, pharyngeal weakness, and arthrogryposis, involving predominantly the lower limbs. Less constant features include facial diplegia, 
diaphragmatic paralysis, respiratory failure, decreased gastrointestinal-tract motility, congenital cataracts, and electrocardiographic abnormalities. Surviving infants exhibit delayed motor development and are often mentally retarded. Typically, affected infants have an inverted V-shaped upper lip, which is characteristic of significant bilateral facial weakness. It is noteworthy that myotonia is not observed in the first years of life (Schara and Schoser, 2006).

\subsection{Prognosis and diagnosis of DM1}

Life expectancy appears to be reduced in patients with DM1 and is variable depending on the clinical phenotype presented. Subjects with adult-onset DM1 have a nearly normal Quality of life (QOL) during childhood and early adulthood. Nevertheless, many patients become severely disabled by the fifth or sixth decades of life. Chest infections partly due to aspiration and diaphragm weakness are common and may precipitate respiratory failure. Sudden cardiac death is not uncommon, even in younger patients, but it may be preventable by cardiac pacemaker implantation (Machuca-Tzili L et al., 2005). In addition, treatment for diabetes mellitus including annual measurement of serum glucose and glycosylated hemoglobin concentration is indicated to improve the QOL of these patients. Approximate average age of death for patients with adult-onset disease is between 50 and 60 years, and when symptoms begin in the childhood stage, life expectancy is not necessarily reduced, but complications are more common.

In congenital DM1, stillbirths are seldom reported. In severe cases, mortality is high in the first hours and days of life, caused by respiratory insufficiency despite active resuscitation. After the neonatal period, prognosis is more favorable, and despite retarded motor development, all patients become able to walk independently at different ages. Death is frequent in these patients before the age of 30 years, which is caused suddenly by cardiomyopathy and cardiac arrhythmias (Harper, 2001). In the second decade of life, myotonia becomes a more prominent feature, in addition to classical symptoms observed in the adult-onset form, such as infertility and gastrointestinal problems.

An accurate diagnosis of DM1 is important, not only to enable a differential diagnosis among neurological diseases, but also to predict disease severity and to assist patients with appropriate medical monitoring and symptom management. For some time, clinical features were employed to establish the diagnosis of DM1; however, the disease's multisystemic and variable symptomatology caused misdiagnosis in some instances. For example, congenital DM1 could be clinically confused with several other congenital neuromuscular disorders, including myotonia congenita, congenital myopathies, spinal muscular atrophy type 1 or -2 , congenital myasthenic syndromes, Möbius syndrome, Spinal muscular atrophy with respiratory distress (SMARD1), the congenital form of glycogenosis type 2, or anoxic brain damage (Harper, 2001; Harper \& Monckton, 2004). In adults, Myotonic dystrophy type 2 (DM2) is the condition that is most similar to DM1; the symptoms are practically the same in both dystrophies. Other hereditary distal myopathies, such as hereditary myofibrillar myopathy, hereditary inclusion body myositis, distal muscular dystrophy (Miyoshi, Nonaka, Welander, Markesbery-Griggs), or limb-girdle muscular dystrophies could be confused (Bird, 2011). Currently, diagnosis of DM1 disease is based on DNA testing in individuals who are clinically suspected of having DM1. Patients may have had an electromyography and occasionally muscle biopsy and other tests prior to clinical suspicion 
of the diagnosis. Electromyography was the most helpful laboratory study prior to the availability of genetics. The combination of myotonic discharges and myopathic- appearing motor units, predominantly in distal muscles and the face, is highly suspicious of DM1. Because electrical myotonic discharges are not usually observed during infancy and many other disorders are associated with myotonia, including myotonia and congenital parmyotonia, this particular test should be taken only as a suggestive finding of DM1. Muscle biopsy is histologically grossly abnormal in clinically affected individuals. Features include variability in fiber size, fibrosis, rows of internal nuclei, sarcoplasmic masses, and an increased number of intrafusal muscle fibers. However, it should be emphasized that there is no clinical indication for performing a muscle biopsy to conducting the diagnosis of DM1 (The International Myotonic Dystrophy Consortium [IDMC], 2000). If clinical features suggest DM1 but DM1 genetic testing is negative, then DM2 testing should be performed. Finally, serum creatine kinase concentration may be mildly elevated in patients with DM1, but it is often normal in asymptomatic individuals.

The DNA test for DM1 is highly relevant because, it confirms the diagnosis in cases with clinically uncertain symptoms, eliminating the need for invasive muscle biopsy. Currently, molecular diagnosis identifies the DM1 mutations in 100\% of affected subjects (IDMC, 2000). In addition, determination of insert sizes of CTG repeats aids relatively in predicting disease severity (see Table 1), which is especially useful in young asymptomatic subjects. Despite several advances in the field of DNA analytic techniques, identification of DM1 expanded alleles continues to represent a challenge because of the immense length and variability of expanded alleles and due to the extremely stable secondary structure formed by repetitive, CG-rich sequences. Mutation analysis is based on detection of expanded DMPK alleles, usually by Southern blot analysis. The use of Field-inversion gel electrophoresis (FIGE) and Pulsed-field gel electrophoresis (PFGE), as well as digoxigenin-labeled short CAG-repeatspecific, locked nucleic acid probes have increased the resolution of this technique (Jakubicza et al., 2004). However, Southern blot analysis is not suitable for routine clinical use because it is a time-consuming technique that requires large amounts of genomic DNA and the use in the majority of instances of radioactive probes. Moreover, Southern blot fails to detect premutated alleles and alleles with small expansions. PCR-based assays have been developed to replace Southern blot. PCR utilizing flanking primers allows for amplification up to approximately 100 CTG repeats, but it is unreliable above this size; thus, amplification of alleles with very large numbers of CTG repeats $(>100)$ continue to require Southern blot analysis (Falk, 2006; Tishkoff, 1998; Warner, 1996). Certain improvements in amplification of alleles with large numbers of repeats have been obtained by adding highly stable Taq DNA polymerases, and PCR-enhancing agents, such as glycerol, betaine, and 7-deaza-dGTP to the master reaction (Cheng et al., 1996; Kakourou et al., 2010; Magaña et al., 2011a; SkrzypczakZielinska et al., 2009). Currently, identification of DM1 expanded alleles is performed through fluorescent PCR and capillary electrophoresis. The use of a fluorescently labeled primer permits detection of the amplified products by an Argon lasser, and its comparison with a molecular size marker allows sizing of alleles of $<100$ CTG repeats. Interestingly, a simple fluorescent PCR system that can rapidly identify the largest alleles for any disorder with CTG/CAG repeat expansion was developed (Warner et al., 1996). This method utilizes a fluorescently labeled locus-specific primer flanking the CTG repeat together with paired primers amplifying from multiple priming sites within the CTG repeat. Triplet repeat primed (TP-PCR) gives a characteristic ladder on the fluorescent trace, enabling rapid 
identification of large, pathological CTG repeats that cannot be amplified employing flanking primers. Although TP-PCR detects expanded alleles of all lengths, it does not allow for their sizing. In fact, samples with large CTG expansions identified by TP-PCR will require Southern blotting if accurate estimation of size is required (Magaña et al., 2011a). Therefore, there is no single method available yet that can reliably identify and size all ranges of expanded alleles in the DM1 locus.

\section{Genetics of DM1}

DM1 is the most common type of myotonic dystrophy in adults and it belongs to a growing group of genetic diseases caused by expansion of unstable microsatellite repeats. In 1992, DM1 was shown to be caused by an expanded CTG repeat in the 3'-Untranslated region (3'UTR) of the Dystrophy myotonic-protein kinase (DMPK) gene in chromosome 19q (Brook et al., 1992) (Figure 1). This gene is composed of 15 exons that encode several alternatively spliced isoforms of a serine/threonine protein kinase that range from 60-70 kDa. The number of CTG repeats in the DMPK gene is polymorphic. In unaffected individuals, length of the CTG expansion ranges from 5-34 repeats; this range of repeats is stably inherited and possesses a relatively low mutation rate. DM1 alleles present a range of intermediate alleles that is known as the "premutation range" and that includes between 35 and 49 CTG repeats (Table 1); this range is not clinically significant, but it is genetically unstable, which may cause the expansion of repeats in subsequent generations to reach the pathological range (IDMC, 2000), whereas affected individuals with as few as 50 repeats can exhibit symptoms of the disease in adulthood (Table 1).

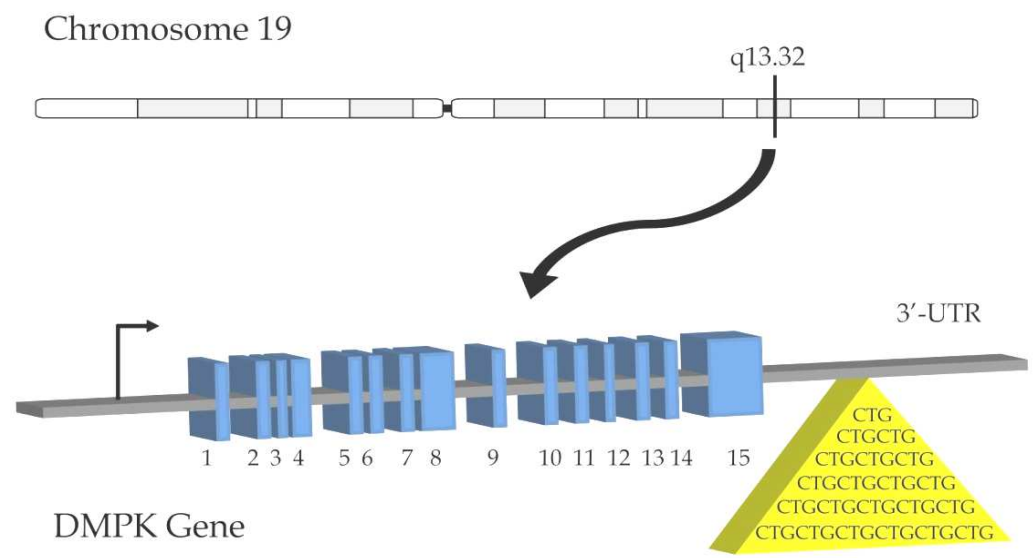

Fig. 1. DMPK gene. The DMPK gene is located in chromosome 19 at the q13.32 band. Blue rectangles indicate exons and the straight gray line, introns. The CTG repeat tract is located in the $3^{\prime}$ unstranslated region of the gene.

In DM1, puzzling genetic phenomena, such as anticipation and the congenital form, which were difficult to explain by conventional Mendelian genetics, are largely attributable to the "dynamic" mutation. Expanded repeat size correlated inversely with age-at-onset, and repeat size increases in successive generations in DM1, providing the molecular basis for anticipation (Harper et al., 1992; Harley et al., 1992; Ashizawa et al., 1992). Paternal mutant 
alleles usually do not exceed 1,000 CTGs in offspring, whereas maternal transmission frequently gives rise to further expansions of mutant repeats beyond 1,000 CTGs in children with congenital myotonic dystrophy (Lavedan et al., 1993; Ashizawa et al., 1994). Premutation alleles tend to expand into the full-mutation range more frequently with paternal than with maternal transmission (Martorell et al., 2001; 2004). This accounts for the paternal origin of the de novo mutations of myotonic dystrophy. The terminal event of anticipation in DM1 is the congenital form, which accompanies severely compromised nuptial and reproductive capability. Consequently, anticipation is expected to deplete the population of patients with DM1 in gradual fashion. However, the prevalence of the disease has been relatively steady; in part, this can be explained by the considerable pool of normal individuals who have permutation alleles who can act as a reservoir for the future origin of new cases through genetic instability (Martorell et al., 2001).

\begin{tabular}{c|c|c}
\hline Phenotype & CTG repeat size & $\begin{array}{c}\text { Age-at-onset } \\
\text { (years) }\end{array}$ \\
\hline Normal & $5-34$ & NA \\
Premutation & $35-49$ & NA \\
Adult-onset (Mild) & $50-150$ & $60-70$ \\
Adult-onset (Classic) & $100-1,000$ & $10-30$ \\
Congenital & $>1,000$ & From birth to 10 \\
\hline
\end{tabular}

Table 1. Correlation between CTG repeat length and phenotype in DM1. NA, Not applicable.

\subsection{Origin and distribution of the CTG repeat polymorphism}

Myotonic dystrophy is one of the most common inherited neuromuscular disorders and has been described in global populations except for the majority of sub-Saharan ethnic populations (Krahe et al., 1995; Ashizawa \& Epstein, 1991). Prevalence varies but generally ranges from 1/8,000-1/50,000 in European and Japanese populations (Harper et al., 2002). High prevalence has been reported in different regions of the world, such as Northeastern Quebec, Canada (Bouchard et al., 1989), and Istria, Croatia (Medica et al., 2004), with a founder effect. Based on the paucity of DM1 in sub-Saharan ethnic populations, it was postulated that the DM1 mutation occurred after human migration out of Africa (Ashizawa \& Epstein, 1991). When the (CTG) $)_{n}$ DM1 mutation was identified, it was found to be in complete linkage disequilibrium with the Alu 1-kb insertion $\left(\mathrm{Alu}^{+}\right)$allele located $5 \mathrm{~kb}$ upstream of the (CTG) $n$ repeat within the DMPK gene (Zerylnick et al., 1995). Since then, $(\mathrm{CTG})_{n}$ repeat expansion has always been found on the $\mathrm{Alu}^{+}$background in European and Asian populations (Krndija et al., 2005; Pan et al., 2001), with the exception of a Nigerian Yoruba family (Krahe et al., 1995). Subsequent analyses of (CTG) $n$ and the $\mathrm{Alu}^{+} /$polymorphism in populations worldwide appears to point to the consensus that (CTG) $\mathrm{Alu}^{+}$is the ancestral haplotype for all observed haplotypes and that (CTG $)_{n}$ expansion alleles have derived from this ancestral haplotype through expansion in successive generations of larger normal alleles with $>18$ CTG repeats (Tishkoff et al., 1998). Supporting this hypothesis, African-Negroid, African-American, and Taiwanese populations all exhibit low frequency of (CTG) >18 alleles and low DM1 prevalence (Acton et al., 2007; Goldman et al., 1994; Hsiao et al., 2003; Pan et al., 2001), whereas the relatively high frequency of (CTG) >18 
alleles observed in Japanese, Yugoslav and European populations appears to be associated with moderate-to-high incidence of DM1 (Leifsdottir et al., 2005; Mladenovic et al., 2006). Thus, in the absence of epidemiological data for DM1, frequency estimation of (CTG) ${ }_{n}$ alleles with $>18$ repeats in healthy population could be an indirect estimator of DM1 prevalence (Magaña et al., 2011).

Analysis of haplotypes of the DMPK region demonstrated that the majority of European and Asian DM1 (CTG) $)_{n}$ expanded alleles are on one haploytpe (haplotype A) background, while the Nigerian DM1 mutation was found to be on a different haplotype background (Krahe, et al., 1995). Therefore, (CTG) $)_{5}$ repeats in the DMPK gene is the most common allele in the majority of the populations; however, allelic distribution of other alleles is different among populations by means of the genetic drift effect on these populations or due to the genic flow caused by the emergence of new populations.

\subsection{Expansion and Instability of CTG repeats}

The molecular mechanism underlying repeat instability has yet to be completely elucidated. However, remarkable progress has been achieved through research done not only in patient-derived tissues and cells, but also in a variety of experimental systems, including in vitro, bacteria, yeast, and transgenic animal models. The use of these experimental models has recapitulated the expansion-prone instability of the expanded (CTG) ${ }_{n}$ repeat, with degree of repeat instability in correlation with repeat size.

Age-dependent, tissue-specific somatic CTG repeat instability is observed in patients with DM1, with a strong bias toward expansions. The first wave of somatic instability has been suggested to occur between 13 and 16 weeks of gestation, and the second, which is less than the first, could continue throughout adulthood (Jansen et al., 1994). Likewise, a high degree of instability is detected in germ cells. In male gametes, smaller repeats are highly unstable, tending to enlarge significantly during spermatogenesis, while in female gametes, high instability is exhibited mainly in larger repeats (Martorell et al., 2004). It is thought that CTG repeats have already expanded in DM1-affected oocytes, leading to the conclusion that the initial CTG expansion occurs prior to completion of meiosis II of oogenesis (De Temmerman et al., 2004). In transgenic mice, the expanded (CTG) $)_{n}$ repeat exhibits the majority of the characteristics of the expanded repeat in patients' tissues, including expansion bias, the parental gender effect, intergenerational instability, age-dependent increase, and inter-tissue variability of the repeat size (Fortune et al., 2000; Gourdon et al., 1997; Monckton et al., 1997; Seznec et al., 2000; 2001). Characterization of transgenic mice with expanded CTG-CAG repeats in the background of mismatch repair-gene deficiencies revealed that Msh2, Msh3, Msh6, and Pms2 play important roles in repeat instability (Savouret et al., 2004; Van den Broek et al., 2002). Studies in vitro provide evidence that CTG-CAG repeats form non-B DNA structures during DNA replication (Wojciechowska et al., 2005); it is thought that the aberrant repair of these DNA intermediates is a source for development of the triplet repeat expansions. In Escherichia coli, CTG repeats are unstable by deletion prone, although expansions do occur depending on repeat length and direction of replication; the mechanism of instability includes slippage of the strands at the replication fork, gene conversion-like events, and recombination (Hashem et al., 2002). Analysis of CTG-CAG repeat instability in yeast has revealed the participation of molecules involved in DNA 
replication and repair (Shimizu et al., 2001). Although studies in bacteria and yeasts have provided insights into the mechanism of CTG repeat instability, their extrapolation to humans should be carefully considered due to obvious interspecies differences. Figure 2 depicts the major contributors to CTGG instability schematically. It is noteworthy that identification of the molecular mechanism causing expansion of CTG repeats might allow the design of therapeutic strategies against DM1, aimed at inducing deletions of the already expanded CTG repeats or preventing expansion from occurring.

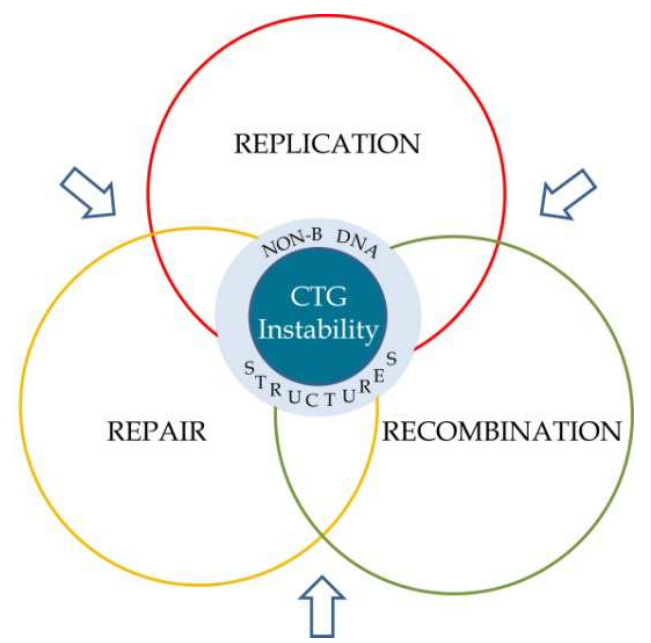

Fig. 2. Major contributors factor to CTG instability in vivo. Studies performed on cells and tissues from subjects with DM1, as well as on organism models including transgenic mice, bacteria, and yeast, have revealed that DNA segments containing expanded CTG repeats form unusual DNA structures that, in conjunction with alterations in the replication, recombination and repair processes, lead to CTG instability.

\section{RNA-mediated mechanisms of pathogenesis}

The mechanism by which the expanded CTG repeat leads to the multisystemic clinical phenotype of DM1 is not fully understood. Because of the location of (CTG $)_{n}$ in the $3^{\prime}$ UTR, the gene's coding region remains intact in the mutant DMPK gene; however, the (CTG) repeat is transcribed into the messenger RNA (mRNA) as a (CUG) $)_{n}$ repeat. Recent studies have led to three major models of the disease mechanism for DM1 as follows: a) DMPK haploinsufficiency; b) loss-of-function of genes in the vicinity of the CTG repeat, and c) a toxic gain-of-function by the expanded CUG repeat in mutant DMPK mRNA.

a. Due to decreased levels of DMPK mRNA and protein in adult DM1 tissue (Fu et al., 1993), DMPK deficiency was proposed as the pathogenic mechanism of DM1 soon after identification of the DM1 mutation. The functional implications of a reduction in DMPK expression were genetically tested with the generation of knockout mice. DMPK-/- mice develop mild, late-onset, progressive skeletal myopathy, which suggested that DMPK might be necessary for the maintenance of skeletal muscle structure (Reddy et al., 1996). Subsequent divulged showed that DMPK-deficient mice also exhibited some cardiac- 
conduction abnormalities (Berul et al., 2000) and metabolic impairment such as abnormal glucose tolerance, reduced glucose uptake, and impaired insulin-dependent GLUT4 trafficking in muscle (Llagostera et al., 2007). However, the fact that DMPK-/mice demonstrated solely a mild phenotype for only some DM symptoms and that no $D M P K$ point mutations have been associated with a DM1 phenotype strongly suggested that the multi systemic features of DM1 were not caused by simply DMPK haploinsufficiency.

b. A second mechanism proposed to explain the pathogenesis of DM1 is based on the effect exerted by CTG expanded repeats on chromatin structure (Otten \& Tapscott, 1995), which in turn might lead to partial silencing of neighboring DMWD (Dystrophia myotonica-containing WD repeat motif) and SIX5 (Sine oculis homeobox homolog 5) genes (Alwazzan et al., 1999; Klesert et al., 1997; Sarkar et al., 2000). This hypothesis is supported by the fact that DMWD expression levels are reported as decreased in repeat expansion-bearing patients (Alwazzan et al., 1998; Gennarelli et al., 1999). Moreover, mutant analysis in Drosophila has shown that D-Six4, the closest Six 5 homolog in flies, is required for normal development of gonad muscle and mesodermal components. This suggested that human Six 5 could participate in muscle-wasting and testicular-atrophy phenotypes in DM1 (Kirby et al., 2001). However, Six5 knockout mice only develop cataracts that lacked the distinctive iridescent opacities characteristic of cataracts of patients with DM1 (Klesert et al., 2000).

c. Data from patients as well as from transgenic mice and cell lines developed for DM1 modeling have offered compelling evidence in support of the third model, which proposes that CUG repeats in the pathogenic range fold into RNA hairpins that are not exported from the nucleus but that, instead, accumulate within ribonuclear foci, acquiring a new toxic function by trapping essential cellular RNA-binding proteins including alternative-splicing modulators and transcription factors, thus disturbing the gene-expression and alternative- splicing processes, respectively (Davis et al., 1997; Ebralidze et al., 2004; Ranum \& Cooper 2006; Taneja et al., 1995).

\subsection{Nuclear retention of mutant DMPK RNA}

Preferential accumulation of mutant DMPK mRNA in nuclear foci has been observed by the Fluorescent in situ hybridization (FISH) technique in fibroblasts, myoblasts, and neurons from different nerve tissues (cerebral cortex, hippocampus, dentate gyrus, thalamus, substantia nigra, and brainstem) of subjects with DM1 (Davis et al., 1997; Day \& Ranum, 2005; Machuca-Tzili et al., 2005). These findings have also been corroborated in muscle tissue of patients with DM1 by Northern blot analysis (Davis et al., 1997; Klesert et al., 2000; Wang et al., 1994). Furthermore, electron microscopy examination has revealed that the CUG-repeat RNA forms double-stranded RNA (Michalowski et al., 1999), which might impede its export to the cytoplasm. It has been demonstrated that nuclear accumulation of mutant transcripts increases in proportion to the number of CUG repeats, suggesting that the length of the (CUG)n tract strongly determines the formation of nuclear aggregates (Klesert et al., 2000). Furthermore, the number and morphology of ribonuclear foci in DM1 are also quite variable in different cell types and tissues; in proliferating DM1 cells in culture, these RNA-rich accumulations range from a few small foci in fibroblasts to dozens of larger foci in myoblasts. In contrast, only a few nuclear foci are observed in postmitotic cells, such as myofibers and cortical neurons. 
Interestingly, mutant DMPK RNA is able to form ribonucleoprotein complexes by binding to certain RNA-binding proteins (Miller et al., 2000) including modulators of alternativesplicing and transcription factors, which are correspondingly depleted from their normal subcellular localizations (for review, see Llamusi \& Artero, 2008). This aberrant event causes alteration in the normal expression of numerous muscular and neuronal proteins, supporting the multisystemic phenotype of the disease (see later). Given the fact that nuclear accumulation of mutant DMPK RNA is the basis for its toxic function, definition of the steps at which mutant mRNA transport is blocked would aid in improving the definition of the molecular basis of the pathology and eventually, in designing a therapeutic treatment (Mastroyiannopoulos et al., 2005).

\subsection{Alternative-splicing misregulation}

Accumulation of mutant DMPK mRNA in nuclei of muscle and nerve cells facilitates its aberrant union with proteins that participate in the regulation of nuclear processes, such as splicing modulators and transcription factors; thus, the normal function of a number of proteins might be impaired. Mutant mRNA of DM1 is able to interact and form aggregates with proteins that participate in the alternative splicing of pre-mRNAs, such as the Muscleblind-like family (MBNL1, MBNL2, and MBNL3), the CUG-binding protein 2 (ETR3), the Protein kinase RNA-activated (Protein kinase R) PKR enzyme, and the heterogeneous nuclear ribonucleoprotein $\mathrm{H}(\mathrm{hnRNP} \mathrm{H})$, which results in interference in developmentally regulated alternative splicing of defined pre-mRNAs (Fardaei et al., 2002; Jiang et al., 2004; Kanadia et al., 2003; Kuyumcu-Martínez \& Cooper 2006; Mankodi et al., 2001; Miller et al., 2000). Furthermore, DM1 mutation cells activate CUG triplet repeat RNA-binding protein 1 (CUG-BP1), also denominated CUGBP1/Elav-like family member 1 (CELF1), through hyperphosphorylation and stabilization in the cell nucleus (Ho et al., 2005; Philips et al., 1998; Savkur et al., 2001; 2004; Timchenko et al., 2001). It is known that up to $74 \%$ of human genes undergo alternative splicing, during which exons or parts of exons can be skipped during pre-mRNA processing, resulting in the expression of multiple variant mRNAs; therefore, alternative-splicing misregulation could be the best explanation for the multisystemic characteristics of DM1 pathology. The function of these splicing regulators determines the tissue- and developmental phase- specific expression of certain protein isoforms (Taneja et al., 1995). Within this group of splicing regulators, CELF1 and MBNL are those that are best understood. CELF1 and MBNL1 play opposite roles in exon selection in several pre-mRNA transcripts; while MBNL1 promotes the transition of splicing from fetal to adult exons, CELF1 aids in retaining fetal exons. According to current evidence, the abnormal length of the (CUG)n segment determines the entrapment of muscle-bound MBNL proteins in ribonuclear aggregates and in the stabilized expression of CELF1, which in turn causes aberrant pre-mRNA splicing that results in abnormal expression of fetal splice isoforms in the tissues of adult subjects with DM1 (Figure 3).

To date, alterations in at least 14 pre-mRNA alternative-splicing events have been reported (Ranum \& Day, 2006; Magaña et al., 2009), seven of which have been found in skeletal and cardiac muscle, affecting the following genes: TNNT2 (cardiac Troponin T gene); IR (Insulin receptor gene); MTMR1 (Myotubularin-related protein 1); TNNT3 (skeletal muscle Troponin $\mathrm{T}$ gene); RyR (Ryanodine receptor gene); SERCA2 (Sarco/endoplasmic reticulum calcium ATPase 2 gene), and $C l C N-1$ (muscle-specific Chloride Channel) (Charlet et al., 2002; Ho et 
al., 2005; Kimura et al., 2005; Mankodi et al., 2002; Philips et al., 1998; Savkur et al., 2001). Moreover, alterations in the transcript processing of Tau, NMDAR1 (N-methyl-D-aspartate receptor 1), and APP (Amyloid protein precursor) genes have been observed to occur in the brain of subjects with DM1 (De León \& Cisneros, 2008; Jiang et al., 2004) (Figure 3).

It is noteworthy that utilization of transgenic mice and cellular models together with the information obtained in clinical trials has enabled correlation of alterations in transcript maturation with DM1 symptomatology. In subjects with DM1, the presence of an IR genederived mRNA that lacks exon 11 has been described, which results in the synthesis of an insulin-resistant receptor isoform (Savkur et al., 2001). This phenomenon could explain the development of diabetes in these individuals. Likewise, several studies have reported the expression of immature transcripts of RyR and SERCA2 genes in skeletal muscle of patients with DM1; the products of these genes regulate calcium homeostasis during sarcolemma depolarization: at the beginning of muscle contraction, $\mathrm{Ca}^{2+}$ is released from the sarcoplasmic reticulum through ion channels formed by RyR, while SERCA2 pumps the former back to the lumen of the sarcoplasmatic reticulum to restore cytoplasmic $\mathrm{Ca}^{2+}$ levels, consequently inducing muscle relaxation. Thus, alterations in this process could be related with the muscle weakness observed in DM1. With respect to the employment of transgenic mice for studying DM1-associated mis-splicing, it has been reported that a transgenic mouse over-expressing CELF1 exhibits production of alternative TNNT2 gene mRNA with the inclusion of exon 5, which is exclusively observed in fetal tissues (Ho et al., 2005; Timichenko et al., 2001). Troponin $\mathrm{T}$ forms part of a protein complex that regulates actinmyosin interactions during muscle contraction. The fetal isoform is less sensitive to $\mathrm{Ca}^{2+}$, resulting in a weaker cardiac-muscle contraction. Based on these observations, it has been proposed that aberrant processing of the Troponin $\mathrm{T}$ gene transcript might be the cause of the development of arrhythmia and the loss of myocardial function described in patients with DM1. Characterization of a second transgenic mouse that over-expressed CELF1 showed the presence of mRNA from the $C l C N-1$ gene with inclusion of exon 7 in muscle tissue. The presence of exon 7 generates higher degradation of the transcript, with the consequent decrease in levels of the protein, a chloride-channel component (Charlet et al., 2002; Mankodi et al., 2002), which ultimately results in decreased transmembranal conductance of chloride ions in muscle fibers. This physiological alteration correlates with the classic clinical sign of DM1: myotonia. Supporting the crucial role of mis-splicing in the development of DM1, the knockout mouse for the MBLN gene (Mbln1 $\left.\Delta^{3} / \Delta^{3}\right)$ displayed alterations in the alternative splicing of TNNT2, TNNT3, and ClCN-1 genes and consequently developed myotonia and cataracts. Comparison of two mouse models for DM1, one expressing the mutant DMPK RNA and the other null for the Mbnlla gene, revealed that loss of MBNL1a explains only $>80 \%$ of the splicing pathology due to expanded CUG RNA. Mbnl-independent mis-splicing effects were observed particularly on mRNAs for extracellular matrix proteins (Du et al., 2010).

Finally, the generation and characterization of cellular models for DM1 have additionally contributed to the identification of the molecular mechanism underling this pathology. A study on $\mathrm{C} 2 \mathrm{C} 12$ cells, a mouse muscular-cell line, demonstrated that CELF1 sequestration by the mutant $D M P K$ RNA impairs the translation of several myogenesis regulators, including MEF2A (myocyte-specific potentiator factor 2A), MyoD (Myogenin 2), and p21 (CdK 1A inhibitor), which ultimately cause impairment in the muscle differentiation 
program (Ho et al., 2005). Although the brain is considered the second most affected organ in DM1, the molecular basis of this pathology in the nervous system has not yet been elucidated. One of the most distinctive characteristics of brain damage in subjects with DM1 is the presence of hyperphosphorylated Tau aggregates in the neurocortex (Jiang et al., 2004). Tau is expressed abundantly in the peripheral and nervous systems and is especially enriched in the axons of mature and growing neurons, in which it is found associated with microtubules and on which it confers stability. Abnormal phosphorylation of Tau negatively affects its binding to microtubules, and ultimately its function, as has been described in Alzheimer disease. In the human brain, six Tau-protein isoforms are expressed as a result of the alternative splicing of exons 2,3, and 10. Interestingly, expression of Tau isoforms, with the exclusion of exons 2/3 and 10, is favored in subjects with DM1 (Jiang et al., 2004; Wang et al., 2005). Exon 2 encodes for the N-terminal domain of Tau, which interacts with the axonal membrane, whereas exon 10 encodes for a microtubule-binding domain. Therefore, absence of these domains in the protein product might affect the function of Tau as a microtubule-stabilizer molecule, causing, at least in part, the neuronal damage observed in patients with DM1 (Wang et al., 2005). As mentioned previously, the brain of subjects with DM1 also exhibits alterations in NMDAR1-gene transcript maturation (Jiang et al., 2004), specifically in cortical and subcortical neurons. NMDAR1 regulates synaptic transmission of excitation in the hippocampus, thus participating in the long-term potentiation and learning process (Tsien et al., 1996). Normally, the NMDAR1 gene produces eight isoforms derived from alternative splicing of its premRNA; nevertheless, patients with DM1 preferentially produce an isoform with the inclusion of exon 5, which affects the affects the receptor's distribution and pharmacological properties. Hence, the presence of this abnormal isoform of NMDAR1 might be related with DM1-associated memory impairment (Cull-Candy et al., 2004; Winblad et al., 2006).

\subsection{Leaching of transcription factors from chromatin}

It has been recently observed that several transcription factors are sequestered by mutant DMPK RNA in muscle cells of subjects with DM1, including Sp1 (Specific protein 1), STAT1, and STAT3 (members of Signal transduction-family proteins and transcription activators), and the gamma subunit of the Retinoic acid receptor (RARY) (Figure 3). This aberrant event removes the transcription factors from active chromatin, leading to disrupted geneexpression patterns. It is thought that the decreased $\mathrm{ClCN}-1$ gene expression observed in the muscle cells of patients with DM1 is due to the entrapment of Sp1 in nuclear foci containing mutant DMPK RNA, because Sp1 modulates the $C l C N-1$ gene promoter positively. Supporting this idea, expression of the $\mathrm{ClCN}-1$ gene is restored in DM1 muscle cells by overexpression of Sp1 (Ebralidze et al., 2004). Further studies are required to fully understand the influence of mutant DMPK RNA on gene expression.

\section{Perspectives of gene therapy}

At present, treatment for DM1 is limited to symptomatic intervention and there is no therapeutic approach to prevent or reverse disease progression. However, elucidation of the molecular mechanisms underlying DM1 pathogenesis have allowed for the envisaging and developing of experimental approaches with therapeutic potential that are aimed at reversing DM1 symptomatology. Because the central core of DM1 pathogenesis is the gain- 


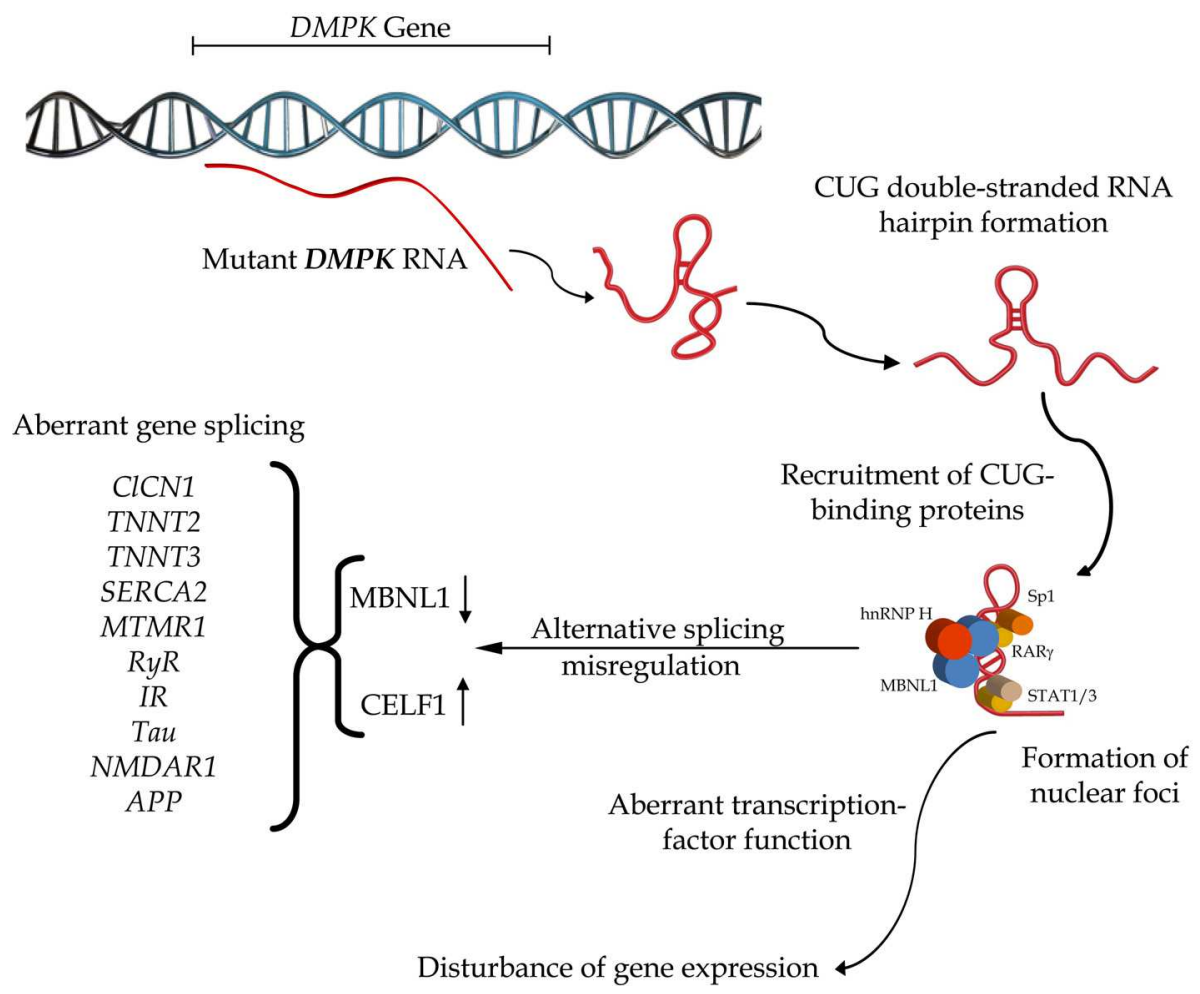

Fig. 3. RNA toxic gain-of-function model for DM1 pathogenesis. Mutant DMPK RNA accumulates in the nucleus of muscle and nerve cells, sequestering different regulatory proteins including splicing modulators MBNL1 and hnRNP H and transcription factors Sp1, STAT1, STAT3, and RARy. Furthermore, expression of expanded CTG repeats causes, by means of an unknown mechanism, an increase in the activity of splicing modulator CELF1. The aberrant behavior of mutant DMPK RNA alters the activity of both splicing modulators and transcription factors, giving rise to impairment in the expression and function of a number of genes and ultimately, to the multisystemic DM1 phenotype.

of-function of mutant DMPK RNA, the majority of studies have been focused on targeting the mutant transcript to eliminate or ameliorate its toxic effects. However, alternative strategies centered on reversing DM1-associated spliceopathy without targeting the mutant DMPK RNA have remerged recently (Magaña \& Cisneros, 2011; Mulders et al., 2010).

\subsection{Degradation or neutralization of mutant DMPK RNA}

Different approaches have been applied to target and cleave mutant DMPK RNA, including the use of antisense RNA, Antisense oligonucleotides (AONs), small interfering RNA (siRNA), and self-cleaving hammerhead ribozymes (Figure 4A). Antisense RNA complementary to (CUG) 13 repeat-sequence AON was employed in human DM1 myoblasts carrying 750 CTG repeats (Furling et al., 2003), resulting in preferential decay of mutant over wild-type DMPK transcripts and consequent normalization of myoblast fusion and 
glucose uptake via restoration of the expression and binding activity of CELF1. Further studies with a 2'-O-Methyl-phosphorothioate-modified AON (2'-MePS-AON) that targets CUG repeats were performed in immortal mouse myoblasts expressing the human DMPK gene with 500 CTG repeats (DM500 cell model) (Mulders et al., 2009) and in two following DM1 mouse models: the first carrying the Human skeletal alpha-actin (HSA) gene modified by the insertion of 250 CTG repeats in the 3'UTR (HSALR mouse model) and the second, bearing the human DM1 locus with 500 CTG repeats (DM500 mouse model) (Mankodi et al., 2000; Seznec et al., 2000). Promisingly, antisense treatment resulted in decreasing levels of mutant $D M P K$, reduction of ribonuclear foci, and correction of the DM1-associated, aberrant pre-mRNA splicing of several genes. Similar positive effects have been observed in DM1 myoblasts that have $\sim 3,200$ CTG repeats with the use of siRNAs (Langlois et al., 2005), and in DM1 myoblasts expressing approximately 750 CTG repeats with the employment of nuclear ribozymes that targeted and cleaved 3'UTR of DMPK mRNA (Langlois et al., 2003). However, the main limitation of these strategies lies in that all molecules recognize and cleave both mutant and wild-type DMPK mRNA with similar efficacy.

A more recent and attractive strategy against DM1 postulates that disruption of the aberrant RNA-protein interactions exerted by the DMPK mutant transcript with the alternativesplicing regulator MBNL1 would correct DM1-associated mis-splicing (Figure 4B). Supporting this hypothesis, a 25-nucleotide morpholino-type AON complementary to CUGrepeated RNA blocks the formation of the CUG-expanded MBNL1 complex in the HSALR transgenic mouse model, resulting in several beneficial effects, including decreased number of nuclear foci through MBNL1 protein redistribution in the nucleus, enhanced transport of CUG expanded-containing transcripts to the cytoplasm, alternative-splicing correction of MBNL1-dependent genes, normalization of transmembrane chloride-ion conductance, and reduction of myotonia (Wheeler et al., 2009). In this regard, identification of small molecules or multivalent modular compounds that specifically bind CUG repeats and that could competitively release sequestered MBNL1 would constitute a promising alternative strategy for neutralization of toxic RNA (Warf and Berglund, 2010; Warf et al., 2009).

\subsection{Mis-splicing reversal}

Sequestration of MBNL1 by mutant DMPK transcript in nuclear foci indicates that MBNL1 titration and loss-of-function is linked with the mis-splicing of particular genes. Furthermore, it was recently shown that activation of the PKC signaling pathway by CUG repeats leads to CELF1 hyperphosphorylation and stabilization, implicating this signaling event in DM1-associated mis-splicing (Philips et al., 1998; Savkur et al., 2001; Sergeant et al., 2001). Therefore, it has been hypothesized that modulation of the expression and/or activity of these two splicing factors would reverse DM1-associated spliceopathy (Figure 4C). Consistent with this idea, over-expression of MBNL1 in a Drosophila model of DM1 expressing a non-coding mRNA containing 480 CUG repeats reduced the number of nuclear foci and suppressed the degenerative phenotypes caused by expanded repeats in muscle and eye tissue (de Haro et al., 2006). Moreover, over-expression of MBNL1 mediated by an adeno-associated viral vector specifically corrected the mis-splicing of MBNL1-dependent genes including Clcn1, Serca1, and Tnnt3 and reversed myotonia in the HSALR mouse model of DM1 (Kanadia et al., 2006). On the other hand, different mice models have been established to test the role of CELF1 activity in the development of muscle-wasting and cardiac disease in DM1 (Ho et al., 2005; Koshelev et al., 2010). Interestingly, specific blockage 
of PKC activity in an inducible mouse model for heart-specific expression of 960 CUG RNA repeats that developed cardiac arrhythmias, cardiomyopathy, and CELF1-associated spliceopathy (Wang et al. 2007) resulted in improved cardiac conduction and reduced misregulation of CELF1-mediated splicing events, which correlated with decreased phosphorylation and steady-state levels of CELF1 (Wang et al., 2009). Hence, the use of protein kinase $\mathrm{C}$ inhibitors to downregulate or to prevent upregulation of CELF1 activity would be an alternative therapeutic treatment for DM1. Finally, it is important to mention that correction of DM1 mis-splicing by modulation of CELF1 and MBNL1 expression should be considered with caution because artificial alteration of MBNL1 and/ CELF1 steady-state levels might alter the splicing pattern of a number of genes regulated by these proteins, with unknown consequences for muscle function.

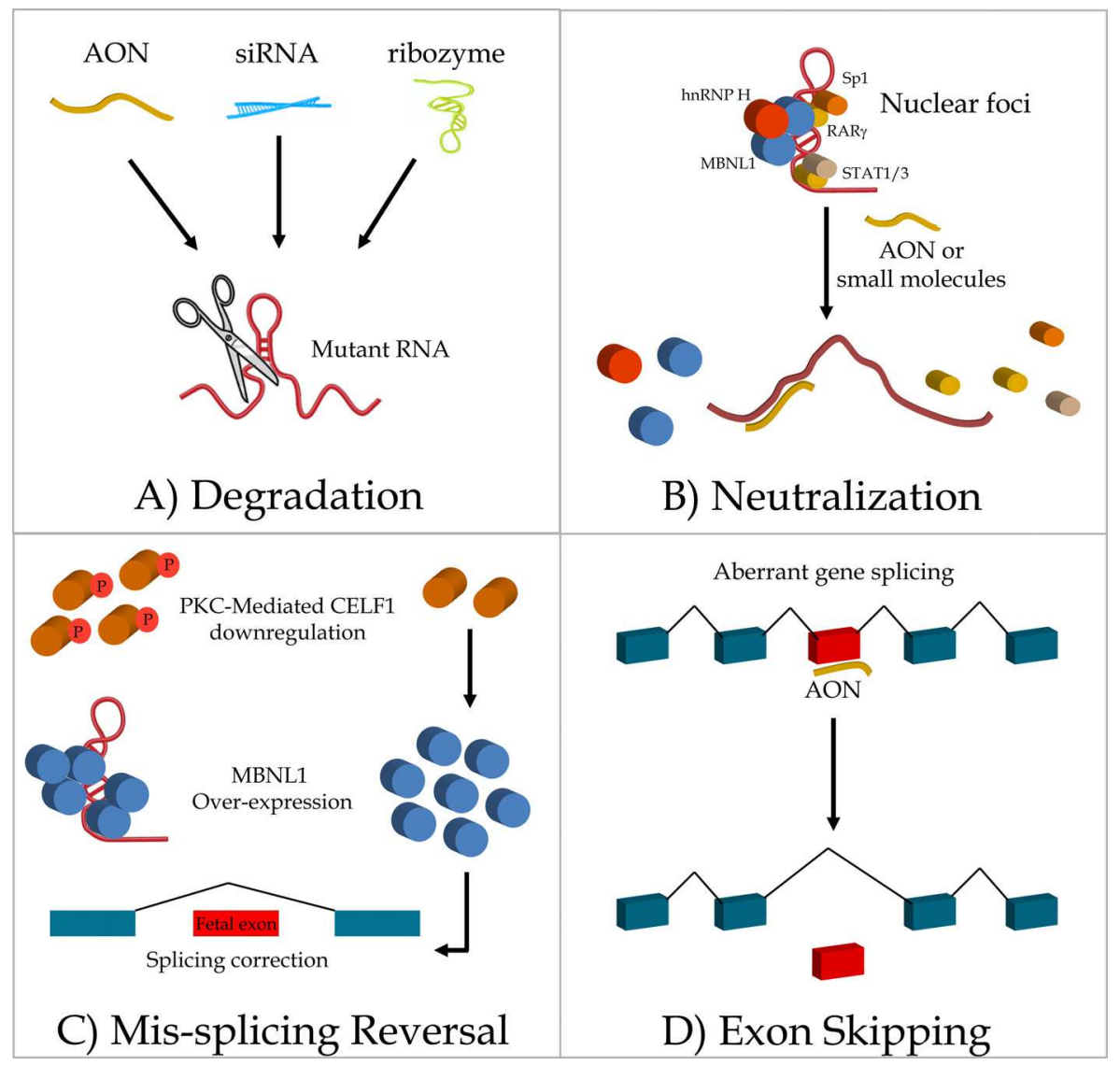

Fig. 4. Strategies for DM1 gene therapy. A) Degradation of mutant RNA by antisense oligonucleotides (AON), ribozyme, or siRNA. B) Neutralization of mutant RNA activity by blocking its interaction with the splicing regulator MBNL1 using AON or small chemical compounds. C) Mis-splicing reversal by ver-expression of MBNL1 or down-regulation of CELF activity. D) Exon skipping of mis-spliced genes (i.e. CLCN1 gene) by splicing blockage with AON. 


\subsection{Exon skipping of mis-spliced genes}

An alternative strategy to fight DM1 symptomatology is to correct aberrant splicing events by exon skipping of mis-spliced genes. The mechanism of exon skipping is based on the binding of AON to specific-target sense sequences of mis-spliced pre-mRNA genes to block the access of splicing machinery to splice sites, causing the elimination of specific exons(s) and their flanking regions, in order to restore an open-reading frame of the normal isoform (Alter et al., 2006; Lu et al., 2005) (Figure 4D). AON-mediated exon skipping appears to be a potent method for reversing DM1-associated myotonia caused by abnormal inclusion of exon $7 \mathrm{a}$ in $\mathrm{ClCN}-1$ mRNA. Normalization of $\mathrm{ClCN}-1$ current density, as well as elimination of myotonic discharges, were observed in two murine models (DM1 mouse model HSALR, and a transgenic mouse homozygous for MBNL1-gene disruption) after muscular injection of a morpholino-AON that targeted the 3' splice site of $\mathrm{ClCN}-1 \mathrm{mRNA}$ exon 7a and prevented inclusion of this exon in the mature transcript (Wheeler et al., 2007). Future exonskipping strategies for DM1 should ensure muscle-specific uptake of therapeutic oligos after their systemic delivery, as well as the employment of a multiple AON cocktail designed to correct splicing at two or more transcripts involved in DM1 symptomatology.

\section{Conclusions and future outlook}

Conventional approaches to treatment of DM1 are supportative and have failed to slow or halt disease progression. Substantial progress has been made in understanding the diseasecausing mechanisms of DM1, and now that it is clear that multisystemic phenotype of DM1 results directly from expression of a mutant expanded repeat RNA, the search for novel therapies is underway. Despite the tremendous progress obtained in several cell-based and animal models, in which degradation or neutralization of the mutant DMPK RNA results in reversal of mis-splicing and myotonia, there are a number of hurdles to overcome before implementation of RNA-based strategies in clinical trials, such as tissue-specific delivery, sustainability, and effectiveness of the therapeutic molecules.

\section{Acknowledgments}

This work was supported by the Science and Technology Institute of Mexico City (ICyTDF), Grant PIFUTP08-164.

\section{References}

Acton, R.T.; Rivers, C.A.; Watson, B.; \& Oh S.J. (2007). DMPK-associated myotonic dystrophy and CTG repeats in Alabama African Americans. Clinical Genetics, Vol. 72, pp. 448-453, ISSN 0009-9163

Alter, J.; Lou, F.; Rabinowitz, A.; Yin, H.; Rosenfeld, J.; Wilton, S.D.; Partridge, T.A.; \& Lu, Q.L. (2006). Systemic delivery of morpholino oligonucleotide restores dystrophin expression bodywide and improves dystrophic pathology. Nature Medicine. Vol.12, No.2, pp.175-177., ISSN 1078-8956

Alwazzan, M.; Hamshere, M.G.; Lennon, G.G.; \& Brook, J.D. (1998). Six transcripts map within 200 kilobases of the myotonic dystrophy expanded repeat. Mammalian Genome. Vol.9, No.6, pp.485-487, ISSN 0938-8990 
Alwazzan, M.; Newman, E.; Hamshere, M.G.; \& Brook, J.D. (1999). Myotonic dystrophy is associated with a reduced level of RNA from DMWD allele adjacent to the expanded repeat. Human Molecular Genetics.Vol.8 pp.1491-1497, ISSN 0964-6906

Ashizawa, T.; \& Epstein H.F. (1991). Ethnic distribution of myotonic dystrophy gene. Lancet. Vol 338 No. 8767, pp. 642-643. ISSN 0140-6736

Ashizawa, T.; Dunne, C.J.; Dubel, JR.; Perryman, M.B.; Epstein, H.F.; Boerwinkle, E.; \& Hejtmancik, J.F.(1992). Anticipation in myotonic dystrophy. I. Statistical verification based on clinical and haplotype findings. Neurology. Vol 42, No. 10, pp. 1871-1877, ISSN 0028-3878

Ashizawa, T.; Dunne, P.W.; Ward, P.A.; Seltzer, W.K.; \& Richards, CS. (1994). Effects of the sex of myotonic dystrophy patients on the unstable triplet repeat in their affected offspring. Neurology. Vol 44 No.1, pp. 120-122 , ISSN 0028-3878

Berul, C.I.; Maguire, C.T.; Gehrmann, J.; \& Reddy, S. (2000).Progressive atrioventricular conduction block in a mouse myotonic dystrophy model. Journal of Interventional Cardiac Electrophysiology. Vol.4, No.2, pp.351-358 ISSN 1383-875X

Bouchard, G.; Roy, R.; Declos, M.; Mathieu, J.; \& Kouladjian, K. (1989). Origin and diffusion of the myotonic dystrophy gene in the Saguenay region (Quebec). The Canadian Journal of Neurological Sciences. Vol 16, No.1,pp. 119-122 ISSN 0317-1671

Brook, J.D.; McCurrach, M.E.; Harley, H.G.; Buckler, A.J.; Church, D.; Aburatani, H.; Hunter, K.; Stanton, V.P.; Thirion, J.P.; \& Hudson, T. (1992). Molecular basis of myotonic dystrophy: expansion of a trinucleotide (CTG) repeat at the 3 ' end of a transcript encoding a protein kinase family member. Cell, Vol 68, No.4, pp.799-808, ISSN 0092-8674.

Charlet, B.N.; Savkur, R.S.; Singh, G.; Philips, A.V.; Grice, E.A.; \& Cooper, T.A. (2002). Loss of the muscle-specific chloride channel in type 1 myotonic dystrophy due to misregulated alternative splicing. Molecular Cell 2002; Vol. 10, pp.45-53, ISSSN 10972765

Cheng, S.; Barceló, J.M.; \& Korneluk, RG. (1996). Characterization of large CTG repeat expansions in myotonic dystrophy alleles using PCR. Human Mutation, Vol. 7, No.4 , pp. 304-310, ISSN 1059-7794

Cull-Candy, S.G.; \& Leszkiewicz, D.N.(2004). Role of distinct NMDA receptor subtypes at central synapses. Science's STKE: signal trasduction knowledge environment. 2004; re16 ISSN 1525-8882

Davis, B.M.; McCurrach, M.E.; Taneja, K.L.; Singer, R.H.; \& Housman, D.E. (1997). Expansion of a CUG trinucleotide repeat in the $3^{\prime}$ untranslated region of myotonic dystrophy protein kinase transcripts results in nuclear retention of transcripts. Proceedings National Academy Sciences of United States of America, Vol.94, No.14, pp.7388-7393, ISSN 0027-8424

Day, J.W. \& Ranum, L.P.; (2005). RNA pathogenesis of the myotonic dystrophies. Neuromuscular Disorders, Vol. 15, No.1, pp.5-16, ISSN 0960-8966

De Haro, M.; Al-Ramahi, I.; De Gouyon, B.; Ukani, L.; Rosa, A.; Faustino, N.A.; Ashizawa, T.; Cooper, T.A.; \& Botas, J. (2006). MBNL1 and CUGBP1 modify expanded CUGinduced toxicity in a Drosophila model of myotonic dystrophy type 1. Human Molecular Genetics. Vol.15, No.13, pp.2138-2145, ISSN 0964-6906

De León, M. \& Cisneros, B. (2008). Myotonic dystrophy 1 in the nervous system: From the clinic to molecular mechanisms. Journal Neuroscience Reserch, Vol. 86, No. 1, pp.1826, ISSN 0360-4012 
De Temmerman, N.; Sermon, K.; Seneca, S.; De Rycke, M.; Hilven, P.; Lissens, W.; Van Steirteghem, A.; \& Liebaers, I. (2004). Intergenerational instability of the expanded CTG repeat in the DMPK gene: studies in human gametes and preimplantation embryos. American Journal of Human Genetics Vol.75, No.2, pp. 325-329, ISSN 00029297

Di Costanzo, A.; Di Salle, F.; Santero, L.; Tessitore, A.; Bonavita, V.; \& Tedeschi, G. (2002) Pattern and significance of white matter abnormalities in myotonic dystrophy type 1: an MRI study. Journal of Neurology. Vol.249 , No.9, pp. 1175-82, ISSN 0340-5354

Di Costanzo, A.; Santoro, L.; de Cristofaro, M.; Manganelli, F.; Di Salle, F.; \& Tedeschi, G. (2008). Familial aggregation of white matter lesions in myotonic dystrophy type 1. Neuromuscular Disorders. Vol.18, No.4, pp. 299-305, ISSN 0960-8966

Du, H.; Cline, M.S.; Osborne, R.J.; Tuttle, D.L.; Clark, T.A.; Donohue, J.P.; Hall, M.P.; Shiue, L.; Swanson, M.S.; Thornton, C.A.; \& Ares, M. Jr. (2010) Aberrant alternative splicing and extracellular matrix gene expression in mouse models of myotonic dystrophy. Nature structural \& molecular biology.2010 Feb;17(2):pp.187-93. ISSN 1545-9993

Ebralidze, A.; Wang, Y.; Petkova, V.; Ebralidse, K.; \& Junghans, R.P. (2004). RNA leaching of transcription factors disrupts transcription in myotonic dystrophy. Science, Vol 303, No.5656, pp.383-387, ISSN 0036-8075.

Ellegren, H. (2000). Heterogeneous mutation processes in human microsatellite DNA sequences. Nature Genetics, Vol 24, No. 4, pp. 400-402, ISSN 1061-4036.

Falk, M.; Vojtiskova, M.; Lukas, Z.; Kroupová, I.; \& Froster, U. (2006). Simple procedure for automatic detection of unstable alleles in the myotonic dystrophy and Huntington's disease loci. Genetic Testing, Vol. 10, No. 2, pp.85-97, ISSN 1090-6576

Fardaei, M.; Rogers, M.T.; Thorpe, H.M.; Larkin, K.; Hamshere, M.G.; Harper, P.S.; \& Brook, J.D.(2002). Three proteins, MBNL, MBLL and MBXL, co-localize in vivo with nuclear foci of expanded-repeat transcripts in DM1 and DM2 cells. Human Moecular Genetics. Vol.11, No.7, pp.805-814, ISSN 0964-6906

Fortune, M.T.; Vassilopoulos, C.; Coolbaugh, M.I.; Siciliano, M.J.; \& Monckton, D.G. (2000). Dramatic, expansion-biased, age-dependent, tissue-specific somatic mosaicism in a transgenic mouse model of triplet repeat instability. Human Molecular Genetics. Vol.9, No.3, pp. 439-445, ISSN 0964-6906

Fu, Y.H.; Friedman, D.L.; Richards, S.; Pearlman, J.A.; Gibbs, R.A.; \& Pizzuti, A. (1993). Decreased expression of myotonin-protein kinase messenger RNA and protein in adult form of myotonic dystrophy. Science 1993; 36: 59-61 ISSN 0964-6906.

Furling, D.; Doucet, G.; Langlois, M.A.; Timchenko, L.; Belanger, E.; Cossette, L.; \& Puymirat, J. (2003). Viral vector producing antisense RNA restores myotonic dystrophy myoblast functions. Gene Therapy.Vol.10, No.9, pp.795-802, ISSN 0969-7128

García de Andoin, N.; Echeverría, J.; Cobo, A.M.; Rey, A.; Paisán, L.; \& López de Munain, A. (2005). A neonatal form of Steinert's myotonic dystrophy in twins after in vitro fertilization. Fertility and Sterility. Vol.84, No.3 pp. 756, ISSN 0015-0282

Gennarelli, M.; Pavón, M.; Amicucci, P.; Angelini, C.; Menegazzo, E.; Zelano, G.; Novelli, G.; \& Dallapiccola, B. (1999). Reduction of the DM-associated homeo domain protein (DMAHP) mRNA in different brain areas of myotonic dystrophy patients. Neuromuscular Disorders. Vol.9, No.4, pp.215-219, ISSN 0960-8966

Goldman, A.; Ramsay, M.; \& Jenkins, T. (1994). Absence of myotonic dystrophy in southern African Negroids is associated with a significantly lower number of CTG trinucleotide repeats. Journal of Medical Genetics . Vol.31, pp. 37-40, ISSN 002-2593 
Gourdon, G.; Radvanyi, F.; Lia, AS.; Duros, C.; Blanche, M.; Abitbol, M.; Junien, C.; \& Hofmann-Radvanyi, H. (1997). Moderate intergenerational and somatic instability of a 55-CTG repeat in transgenic mice. Nature Genetics. Vol.15, No.2, pp.190- 192, ISSN 1061-4036.

Grover, S.; Fishman, G.A.; \& Stone, E.M. (2002). Atypical presentation of pattern dystrophy in two families with peripherin/RDS mutations. Ophthalmology. Vol.109, pp. 11101117, ISSN 0161-6420

Harley, H.G.; Rundle, S.A.; MacMillan, J.C.; Myring, J.; Brook, J.D.; Crow, S.; Reardon, W.; Fenton, I.; Shaw, DJ.; \& Harper, P.S. (1993). Size of the unstable CTG repeat sequence in relation to phenotype and parental transmission in myotonic dystrophy. American Journal of Human Genetics. Vol.52, No.6, pp.1164-1174 ISSN 0002-9297

Harper, P.S. (2001). Myotonic Dystrophy. WB Saunders (3rd Ed), ISBN 0702021520, London

Harper, P.S.; van Engelen, B.G.; Eymard, B.; Rogers, M.; \& Wilcox, D. (2002). 99th ENMC international workshop: myotonic dystrophy: present management, future therapy. 9-11 Naarden, The Netherlands. Neuromuscular Disorders, Vol.12, No.6, pp. 596-599, ISSN 0960-8966

Hashem, V.I.; Klysik, E.A.; Rosche, W.A.; \& Sinden, R.R.; (2002). Instability of repeated DNAs during transformation in Escherichia coli. Mutation Reserch. Vol.502, No 1-2 , pp. 39-46,ISSN 0027-5107

Ho, T.H.; Bundman, D.; Armstrong, D.L.; \& Cooper, T.A. (2005). Transgenic mice expressing CUG-BP1 reproduce splicing mis-regulation observed in myotonic dystrophy. Human Molecular Genetics Vol.14, No.11, pp.1539-1547, ISSN 0964-6906

Hsiao, K.M.; Chen, S.S.; Li, S.Y.; Chiang, S.Y.; Lin, H.M.; \& Pan, H. (2003). Epidemiological and genetic studies of myotonic dystrophy type 1 in Taiwan. Neuroepidemiology .Vol.22, pp. 283-289, ISSN 0251-5350

Jakubiczka, S.; Vielhaber, S.; Kress, W.; Küpferling, P.; Reuner, U.; Kunath, B.; \& Wieacker, P. (2004). Improvement of the diagnostic procedure in proximal myotonic myopathy/myotonic dystrophy type 2. Neurogenetics. Vol.5, No.1, pp. 55-59, ISSN 1364-6745

Jansen, G.; Willems, P.; Coerwinkel, M.; Nillesen, W.; Smeets, H.; Vits, L.; Howeler, C.; Brunner, H.; \& Wieringa, B. (1994). Gonosomal mosaicism in myotonic dystrophy patients: involvement of mitotic events in (CTG)n repeat variation and selection against extreme expansion in sperm. American Journal of Human Genetics .Vol.54, No.4, pp. 575-585, ISSN 0002-9297

Jiang, H.; Mankodi, A.; Swanson, M.S.; Moxley, R.T.; \& Thornton, C.A. (2004). Myotonic dystrophy type 1 is associated with nuclear foci of mutant RNA, sequestration of muscleblind proteins and deregulated alternative splicing in neurons. Human Molecular Genetics 2004; Vol,13, No. 24, pp.3079-3088, ISSN 0964-6906

Kakourou, G.; Dhanjal, S.; Mamas, T.; Serhal, P.; Delhanty, J.D.; \& SenGupta, S.B. (2010). Modification of the triplet repeat primed polymerase chain reaction method for detection of the CTG repeat expansion in myotonic dystrophy type 1: application in preimplantation genetic diagnosis. Fertility and Sterility. Vol.94, No.5, pp. 16741679, ISSN 0015-0282

Kanadia, R.N.; Johnstone, K.A.; Mankodi, A.; Lungu, C.; Thornton, C.A.; Esson, D.; Timmers, A.M.; Hauswirth, W.W.; \& Swanson, M.S.(2003). A muscleblind knockout model for myotonic dystrophy. Science. Vol.302, No.5652, pp.1978-1980 ISSN 0036-8075 
Kanadia, R.N.; Shin, J.; Yuan, Y.; Beattie, S.G.; Wheeler, T.M.; Thornton, C.A.; \& Swanson, M.S. (2006). Reversal of RNA missplicing and myotonia after muscleblind overexpression in a mouse poly(CUG) model for myotonic dystrophy. Proceedings of National Academy of Sciences of United States of America, Vol.103, No.31, pp.1174811753, ISSN 0027-8424

Kim, U.S.; Kim, J.S.; \& Hwang, J.M. (2009). A Case of Myotonic Dystrophy With Pigmentary Retinal Changes. Korean Journal of Ophthalmology ,Vol.23, No.2, pp. 121-123, ISSN 1011-8942

Kimura, T.; Nakamori, M.; Lueck, J.D.; Pouliquin, Aoike F.; Fujimura, H.; Dirksen, R.T.; Takahashi M. P.; Dulhunty, A. F., \& Sakoda, S. (2005). Altered mRNA splicing of the skeletal muscle ryanodine receptor and sarcoplasmic/endoplasmic reticulum $\mathrm{Ca}^{2+}$-ATPase in myotonic dystrophy type 1. Human Molecular Genetics 2005, Vol.14, No. 15, pp.2189-2200, ISSN 0964-6906

Kirby, R.J.; Hamilton, G.M.; Finnegan, D.J.; Johnson, K.J.; \& Jarman, A.P.(2001).Drosophila homolog of the myotonic dystrophy-associated gene, SIX5, is required for muscle and gonad development. Current Biology. Vol.10, No.13, pp. 1044-1049, ISSN 0960-9822

Klesert, T.R.; Otten, A.D.; Bird, T.D.; \& Tapscott, S.J. (1997). Trinucleotide repeat expansion at the myotonic dystrophy locus reduces expression of DMAHP. Nature Genetics. Vol.16, No.4, pp. 402-406, ISSN 1061-4036

Klesert, T.R.; Cho, D.H.; Clark, J.I.; Maylie, J.; Adelman, J.; Snider, L.; Yuen, E.C.; Soriano, P.; \& Tapscott S.J. (2000). Mice deficient in Six5 develop cataracts: implications for myotonic dystrophy. Nature Genetics. Vol.25, No.1, pp.105-109, ISSN 1061-4036

Koshelev, M.; Sarma, S.; Price, R.E.; Wehrens, X.H.; \& Cooper, T.A. (2010). Heart-specific overexpression of CUGBP1 reproduces functional and molecular abnormalities of myotonic dystrophy type 1. Human Molecular Genetics. Vol.19, No.6, pp.1066-1075, ISSN 0964-6906

Krahe, R.; Eckhart, M.; Ogunniyi, A.O.; Osuntokun, B.O.; Siciliano, M.J.; \& Ashizawa, T. (1995). De novo myotonic dystrophy mutation in a Nigerian kindred. American Journal of Human Genetics. Vol.56, No.5, pp.1067-1074, ISSN 0002-9297

Krndija, D.; Savić, D.; Mladenović, J.; Rakocević-Stojanović, V.; Apostolski, S.; Todorović, S.; \& Romac, S. (2005). Haplotype analysis of the DM1 locus in the Serbian population. Acta Neurologica Scandinavica. Vol.111, No.4 , pp. 274-277, ISSN 0001-6314

krzypczak-Zielinska, M.; Sulek-Piatkowska, A.; Mierzejewski, M.; \& Froster, U.G. (2009). New analysis method of myotonic dystrophy 1 based on quantitative fluorescent polymerase chain reaction. Genetic Testing Molecular Biomarkers. Vol.13, No.5, pp.651-655. ISSN 1945-0265

Kuyumcu-Martinez, NM; \& Cooper, TA.(2006). Misregulation of alternative splicing causes pathogenesis in myotonic dystrophy. Progress Moecularl Subcellular Biology, Vol.44, pp. 133-159. ISSN 0079-6484

Laberge, L.; Bégin, P.; Dauvilliers, Y.; Beaudry, M.; Laforte, M.; Jean, S.; \& Mathieu, J. (2009). A polysomnographic study of daytime sleepiness in myotonic dystrophy type 1. Journal of neurology, neurosurgery, and psychiatry, Vol.80, No.6, pp.642-646, ISSN 0022-3050

Langlois, M.A.; Lee, N.S.; Rossi, J.J.; \& Puymirat, J.(2003). Hammerhead ribozyme-mediated destruction of nuclear foci in myotonic dystrophy myoblasts. Molecular Therapy, Vo. 7, No.5 Pt 1, pp 670-680, ISSN 1525-0016

Langlois, M.A.; Boniface, C.; Wang, G.; Alluin, J.; Salvaterra, P.M.; Puymirat, J.; Rossi, J.J.; \& Lee, N.S. (2005). Cytoplasmic and nuclear retained DMPK mRNAs are targets for 
RNA interference in myotonic dystrophy cells. Journal of Biologial Chemistry Vol.280, No.17, pp.16949-16954, ISSN 0021-9258

Lavedan, C.; Hofmann-Radvanyi, H.; Rabes, JP.; Roume, J.; \& Junien, C. (1993). Different sex-dependent constraints in CTG length variation as explanation for congenital myotonic dystrophy. Lancet. Vol.341, No.8839, pp. 237. ISSN 0140-6736

Leifsdóttir, G.; Benedikz, J.E.; Jóhannesson, G.; Jónsson, J.J.; \& Sveinbjörnsdóttir, S. (2005). Prevalence of myotonic dystrophy in Iceland. Laeknabladid. Vol.91, pp. 829-34, ISSN 0023-7213

Liquori, C.L.; Ricker, K.; Moseley, M.L.; Jacobsen, J.F.; Kress, W.; Naylor, S.L.; Day, J.W.; \& Ranum, L.P. (2001). Myotonic dystrophy type 2 caused by a CCTG expansion in intron 1 of ZNF9. Science, Vol.293, No.5531, pp.864-867, ISSN 0036-8075.

Llagostera,E; Catalucci, D; Marti, L; Liesa, M; Camps, M; Ciaraldi, TP; Kondo, R; Reddy, S; Dillmann, WH; Palacin, M; Zorzano, A; Ruiz-Lozano, P; Gomis, R; \& Kaliman, P. (2007).Role of myotonic dystrophy protein kinase (DMPK) in glucose homeostasis and muscle insulin action. PLoS One, Vol. 2, No.11, e1134. ISSN 1932-6203

Llamusi, B; \& Artero, R. (2008). Molecular Effects of the CTG Repeats in Mutant Dystrophia Myotonica Protein Kinase Gene. Current Genomics. Vol.9, No.8, pp.509-516, ISSN 1389-2029

Louprasong, AC.; Light, DJ.; \& Diller, RS. (2010). Spider dystrophy as an ocular manifestation of myotonic dystrophy. Optometry . Vol.81, pp. 188-193, ISSN 1529-1839

Lu, Q.L.; Rabinowitz, A.; Chen, Y.C.; Yokota, T.; Yin, H.; Alter, J.; Jadoon, A.; Bou-Gharios, G.; \& Partridge, T. (2005). Systemic delivery of antisense oligoribonucleotide restores dystrophin expression in body-wide skeletal muscles. Proceedings of National Academy of Sciences of United States of America, Vol.102, No.1, pp.198-203, ISSN 0027-8424

Machuca-Tzili, L; Brook, D; \& Hilton-Jones, D. (2005). Clinical and molecular aspects of the myotonic dystrophies: a review. Muscle \& Nerve , Vol.32, No. 1, pp. 1-18, ISSN 0148$639 X$

Magaña, J.J.; Leyva-Garcia, N.; \& Cisneros, B. (2009). [Pathogenesis of myotonic dystrophy type 1]. Gaceta Medica de Mexico, Vol.145, No.4, pp.331-337, ISSN 0016-3813

Magaña, J.J.; Cortés-Reynosa, P.; Escobar-Cedillo, R.; Gómez, R.; Leyva-García, N.; \& Cisneros, B. (2011). Distribution of CTG repeats at the DMPK gene in myotonic dystrophy patients and healthy individuals from the Mexican population. Molecular Biology Reports. Vol.38, No.2, pp.1341-1346, ISSN 0301-4851

Magaña, J.J. \& Cisneros, B. (2011). Perspectives on gene therapy in myotonic dystrophy type 1. Journal of Neuroscience Research, Vol.89, No.3, pp.275-285, ISSN 0360-4012

Mankodi, A.; Logigian, E.; Callahan, L.; McClain, C.; White, R.; Henderson, D.; Krym, M.; \& Thornton, C.A. (2000). Myotonic dystrophy in transgenic mice expressing an expanded CUG repeat. Science. Vol.289, No.5485, pp.1769-1773, ISSN 0036-8075

Mankodi, A.; Urbinati, C.R.; Yuan, Q.P.; Moxley, R.T.; Sansone, V.; Krym, M.; Henderson, D.; Schalling, M.; Swanson M.S.; \& Thornton, C. (2001) Muscleblind localizes to nuclear foci of aberrant RNA in myotonic dystrophy types 1 and 2. Human Molecular Genetics, Vol.10, No.19, pp. 2165-2170. ISSN 0964-6906

Mankodi, A.; Takahashi, M.P.; Jiang, H.; Beck, C.L.; Bowers, W.J.; Moxley, R.T. Cannon, S. C.; \& Thornton C. A. (2002). Expanded CUG repeats trigger aberrant splicing of 
CIC-1 chloride channel pre-mRNA and Hyperexcitability of skeletal muscle in myotonic dystrophy. Molecular Cell, Vol.10, No.1. pp.35-44, ISSN 1097-2765

Martorell, L.; Monckton, D.G.; Sanchez, A.; Lopez De Munain, A.; \& Baiget, M. (2001). Frequency and stability of the myotonic dystrophy type 1 premutation. Neurology, Vol.56, No.3, pp. 328-335, ISSN 0028-3878

Martorell, L.; Gámez, J.; Cayuela, M.L.; Gould, F.K.; McAbney, J.P.; Ashizawa, T.; Monckton, D.G.; \& Baiget, M. (2004). Germline mutational dynamics in myotonic dystrophy type 1 males: allele length and age effects. Neurology. Vol.62, No.2 pp.269-274, ISSN 0028-3878

Mastroyiannopoulos, NP; Feldman, ML; Uney, JB; Mahadevan, MS; \& Phylactou, LA.(2005). Woodchuck post-transcriptional element induces nuclear export of myotonic dystrophy 3' untranslated region transcripts. EMBO Reports, Vol.6, No.5, pp.458463, ISSN 1469-21X

Matsumura, T.; Iwahashi, H.; Funahashi, T.; Takahashi, M.P.; Saito, T.; Yasui, K.; Saito, T.; Iyama, A.; Toyooka, K.; Fujimura, H.; \& Shinno, S. (2009). A cross-sectional study for glucose intolerance of myotonic dystrophy. Journal of the Neurological Sciences. Vol.276, No.1-2, pp. 60-65, INSS 0022-510X

Medica, I.; Logar, N.; Mileta, D.L.; \& Peterlin, B. (2004). Genealogical study of myotonic dystrophy in Istria (Croatia). Annales Genetique. Vol.47, No.2, pp. 139-146, ISSN 0003-3995

Melacini, P.; Villanova, C.; Menegazzo, E.; Novelli, G.; Danieli, G.; Rizzoli, G.; Fasoli, G.; Angelini, C.; Buja, G.; Miorelli, M. et al. (1995). Correlation between cardiac involvement and CTG trinucleotide repeat length in myotonic dystrophy. Journal of the American Collage of Cardiology. Vol.25, No.1, pp.239- 245, ISSN 0735-1097

Michalowski, S.; Miller, J.W.; Urbinati, C.R.; Paliouras, M.; Swanson, M.S.; \& Griffith, J.(1999). Visualization of double-stranded RNAs from the myotonic dystrophy protein kinase gene and interactions with CUG-binding protein. Nucleic Acids Research.Vol.27, No.17, pp.3534-3542, ISSN 0305-1048

Miller, J.W.; Urbinati, C.R.; Teng-Umnuay, P.; Stenberg, M.G.; Byrne, B.J.; Thornton, C.A.; \& Swanson, M.S.(2000). Recruitment of human muscleblind proteins to (CUG)(n) expansions associated with myotonic dystrophy. The EMBO Journal.Vol. 19, No.17, pp.4439-4448, ISSN 0261-4189

Mladenovic, J.; Pekmezovic, T.; Todorovic, S.; Rakocevic-Stojanovic, V.; Savi, D. Romac, S; \& Apostolski, S. (2006). Epidemiology of myotonic dystrophy type 1 (Steinert disease) in Belgrade (Serbia). Clinical Neurology Neurosurgery. Vol. 108, pp.757-760, ISSN 0303-8467

Monckton, D.G.; Coolbaugh, M.I.; Ashizawa, K.T.; Siciliano, M.J.; \& Caskey, C.T. (1997) Hypermutable myotonic dystrophy CTG repeats in transgenic mice. Nature Genetics. Vol.15, No.2, pp.193-196. ISSN 1061-4036

Mulders, S.A.; Van den Broek, W.J.; Wheeler, T.M.; Croes, H.J.; Van Kuik-Romeijn, P.; De Kimpe, S.J.; Furling, D.; Platenburg, G.J.; Gourdon, G.; Thornton, C.A.; Wieringa, B.; \& Wansink, D.G. (2009). Triplet-repeat oligonucleotide-mediated reversal of RNA toxicity in myotonic dystrophy. Proceedings of National Academy of Sciences of United States of America, Vol.106, No.33, pp.13915-13920, ISSN 0027-8424

Mulders, S.A.; Van Engelen, B.G.; Wieringa, B.; \& Wansink, D.G.( 2010). Molecular therapy in myotonic dystrophy: focus on RNA gain-of-function. Human Molecular Genetics, Vol.19, No.R1, pp.R90-97, ISSN 0964-6906 
Myring, J.; Meredith, AL.; Harley, HG.; Kohn, G.; Norbury, G.; Harper, P.S.; \& Shaw, D.J. (1992) Specific molecular prenatal diagnosis for the CTG mutation in myotonic dystrophy. Journal of Medical Genetics. Vol.29, No.11 pp. 785-788, ISSN 0022-2593

Ono, S.; Takahashi, K.; Kanda, F.; Jinnai, K.; Fukuoka, Y.; Mitake, S.; Inagaki, T.; Kurisaki, H.; Nagao, K.; \& Shimizu, N. (2001). Decrease of neurons in the medullary arcuate nucleus in myotonic dystrophy.Acta Neuropathologica. Vol.102, No.1, pp.89-93, ISSN 0001-6322

Otten, A.D.; \& Tapscott, S.J.(1995) Triplet repeat expansion in myotonic dystrophy alters the adjacent chromatin structure. Proceedings of the National Academy of Sciences of the United States of America.1995 Jun 6; Vol.92, No.12, pp.5465-546, ISSN 0027-8424

Pan, H.; Lin, H.M.; Ku, W.Y.; Li, T.C.; Li, S.Y.; Lin, C.C.; \& Hsiao, K.M. (2001). Haplotype analysis of the myotonic dystrophy type 1 (DM1) locus in Taiwan: implications for low prevalence and founder mutations of Taiwanese myotonic dystrophy type 1 . European Journal of Human Genetics. Vol.9, No.8, pp.638-641. ISSN 1018- 4813

Pearson, C.E; Nichol-Edamura, K.; \& Cleary JD. (2005). Repeat instability: mechanisms of dynamic mutations. Nature Review Genetics, Vol.6, No10, pp.729-742 ISSN 1471-0056.

Philips, A.V.; Timchenko, L.T.; \& Cooper, T.A.(1998). Disruption of splicing regulated by a CUG-binding protein in myotonic dystrophy. Science. Vol.280, No.5364, pp.737-741 ISSN 0036-8075

Ranum, LP; \& Cooper, TA. (2006).RNA-Mediated Neuromuscular Disorders. Annual Review of Neuroscience, Vol. 29, pp. 259-277, ISSN 0147-006X

Reddy, S; Smith, DB; Rich, MM; Leferovich, JM; Reilly, P; Davis, BM; Tran, K; Rayburn, H; Bronson, R; Cros, D; Balice-Gordon, RJ; \& Housman, D. (1996). Mice lacking the myotonic dystrophy protein kinase develop a late onset progressive myopathy. Nature Genetics. Vol.13, No.3, pp.325-335, ISSN 1061-4036

Rosa, N.; Lanza, M.; Borrelli, M.; De Bernardo, M.; Palladino, A.; Di Gregorio, M.G.; Pascotto, F.; \& Politano, L. (2011). Low Intraocular Pressure Resulting from Ciliary Body Detachment in Patients with Myotonic Dystrophy. Ophthalmology. Vol.118, pp.260-264, ISSN 0161-6420

Rubinsztein, J.S.; Rubinsztein, D.C.; Goodburn, S.; \& Holland, A.J. (1998). Apathy and hypersomnia are common features of myotonic dystrophy. Journal of Neurology, Neurosurgery and Psychiatry.Vol.64, No.4, pp.510-515, ISSN 0022-3050

Rubinsztein, J.S.; Rubinsztein, D.C.; McKenna, P.J.; Goodburn, S.; \& Holland, A.J. (1997). Mild myotonic dystrophy is associated with memory impairment in the context of normal general intelligence. Journal of Medical Genetics. Vol.34, No.3 , pp.229-233, ISSN 0022-2593

Sarkar, P.S.; Appukuttan, B.; Han, J.; Ito, Y.; Ai, C.; Tsai, W.; Chai, Y.; Stout, J.T.; \& Reddy, S. (2000). Heterozygous loss of Six 5 in mice is sufficient to cause ocular cataracts. Nature Genetics, Vol. 25, No. 1, pp.110-114, ISSN 1061-4036

Savkur, R.S.; Philips, A.V.; \& Cooper, T.A.(2001).Aberrant regulation of insulin receptor alternative splicing is associated with insulin resistance in myotonic dystrophy. Nature Genetics Vol.29, No.1, pp. 40-47, ISSN 1061-4036

Savkur, R.S.; Philips, A.V.; Cooper, T.A.; Dalton, J.C.; Moseley, M.L.; Ranum, L.P.; \& Day, J.W.(2004). Insulin receptor splicing alteration in myotonic dystrophy type 2. American Journal of Human Genetics.Vol.74, No.6, pp.1309-1313, ISSN 0002-9297 
Savouret, C.; Garcia-Cordier, C.; Megret, J.; te Riele, H.; Junien, C.; \& Gourdon, G. (2004). MSH2-dependent germinal CTG repeat expansions are produced continuously in spermatogonia from DM1 transgenic mice. Molecular Cell Biology. Vol.24, No.2, pp. 629-637.ISSN 0270-7306

Schara, U.; \& Schoser, B.G. (2006). Myotonic dystrophies type 1 and 2: a summary on current aspects. Seminars in Pediatric Neurology, Vol 13, No.2, pp 71-79, ISSN 1071-9091.

Sergeant, N.; Sablonniere, B.; Schraen-Maschke, S.; Ghestem, A.; Maurage, C.A.; Wattez, A.; Vermersch, P.; \& Delacourte, A. (2001). Dysregulation of human brain microtubuleassociated tau mRNA maturation in myotonic dystrophy type 1. Human Molecular Genetics. Vol.10, No.19, pp.2143-2155, ISSN 0964-6906

Seznec, H.; Lia-Baldini, A.S.; Duros, C.; Fouquet, C.; Lacroix, C.; Hofmann-Radvanyi, H.; Junien, C.; \& Gourdon G.(2000). Transgenic mice carrying large human genomic sequences with expanded CTG repeat mimic closely the DM CTG repeat intergenerational and somatic instability. Human Molecular Genetics . Vol.9, No.8, pp.1185-1194, ISSN 0964-6906

Seznec, H.; Agbulut, O.; Sergeant, N.; Savouret, C.; Ghestem, A.; Tabti, N.; Willer, J.C.; Ourth, L.; Duros, C.; Brisson, E.; Fouquet, C.; Butler-Browne, G.; Delacourte, A.; Junien, C.; \& Gourdon, G. (2002). Mice transgenic for the human myotonic dystrophy region with expanded CTG repeats display muscular and brain abnormalities. Human Molecular Genetics. Vol.10, No.23, pp.2717-26, ISSN 0964-6906

Sharma, P.C; Grover, A.; \& Kahl, G.(2007). Mining microsatellites in eukaryotic genomes. Trends in Biotechnology, Vol.25, No. 11, pp. 490-498, ISSN 0167-7799.

Shimizu, M.; Fujita, R.; Tomita, N.; Shindo, H.; \& Wells, R.D. (2001) Chromatin structure of yeast minichromosomes containing triplet repeat sequences associated with human hereditary neurological diseases. Nucleic Acids Research Supplement. No.1, pp.71-72, ISSN 0305-1048

Taneja, K.L.; McCurrach, M.; Schalling, M.; Housman, D.; \& Singer, R.H. (1995). Foci of trinucleotide repeat transcripts in nuclei of myotonic dystrophy cells and tissues.The Journal of Cell Biology. Vol.128, No.6, pp.995-1002, ISSN 0021-9525

The International Myotonic Dystrophy Consortium (IDMC). (2000) New nomenclature and DNA testing guidelines for myotonic dystrophy type 1 (DM1). Neurology, Vol.54, No.6, pp.1218-1221, ISSN 0028-3878

Timchenko, N.A.; Cai, Z.J.; Welm, A.L.; Reddy, S.; Ashizawa, T.; \& Timchenko, L.T.(2001).RNA CUG repeats sequester CUGBP1 and alter protein levels and activity of CUGBP1. The Journal of Biological Chemistry.Vol.276, No.11, pp.7820-7826, ISSN 0021-9258

Tishkoff, S.; Goldman, A.; Calafell, F.; Speed, W.C.; Deinard, A.S.; Bonne-Tamir, B.; Tishkoff, S.; Goldman, A.; Calafell, F.; Speed, W.C.; Deinard, A.S.; Bonne-Tamir, B.; Kidd, J.R,; Pakstis, A.J.; Jenkinns, T.; \& Kidd, T.T. (1998). A global haplotype analysis of the myotonic dystrophy locus: implications for the evolution of modern humans and for the origin of myotonic dystrophy mutations. American Journal of Human Genetics, Vol.62, pp.1389-1402, ISSN 0002-9297

Tsien, J.Z.; Huerta, P.T.; \& Tonegawa, S.(1996).The essential role of hippocampal CA1 NMDA receptor-dependent synaptic plasticity in spatial memory. Cell 1996; 87:pp.13271338, ISSN 0092-8674 
Van den Broek, W.J.; Nelen, M.R.; Wansink, D.G.; Coerwinkel, M.M.; te Riele, H.; Groenen, P.J.; \& Wieringa, B. (2002). Somatic expansion behaviour of the (CTG)n repeat in myotonic dystrophy knock-in mice is differentially affected by Msh3 and Msh6 mismatch-repair proteins. Human Molecular Genetics. Vol.11, No.2, pp .191-198, ISSN 0964-6906

Wang, G.S.; Kearney D.L.; De Biasi, M.; Taffet, G.; \& Cooper, T.A. (2007). Elevation of RNAbinding protein CUGBP1 is an early event in an inducible heart-specific mouse model of myotonic dystrophy. The Journal of Clinical Investigation. Vol.117, No.10, pp.2802-2811, ISSN 0021-9738

Wang, G.S.; Kuyumcu-Martinez, M.N.; Sarma, S.; Mathur, N.; Wehrens, X.H.; \& Cooper, T.A. (2009). PKC inhibition ameliorates the cardiac phenotype in a mouse model of myotonic dystrophy type 1. Journal of Clinical Investigation. Vol.119, No.12, pp.37973806, ISSN 0021-9738

Wang, Y.; Wang, J.; Gao, L.; Lafyatis, R.; Stamm, S.; \& Andreadis, A.(2005). Tau exons 2 and 10 , which are misregulated in neurodegenerative diseases, are partly regulated by silencers which bind a SRp30c.SRp55 complex that either recruits or antagonizes htra2beta1. Journal of Biological Chemistry 2005; 280: pp.14230-14239, ISSN 0021-9258

Wang, Y.H.; Amirhaeri, S.; Kang, S.; Wells, R.D.; \& Griffith, J.D.(1994). Preferential nucleosome assembly at DNA triplet repeats from the myotonic dystrophy gene. Science, Vol. 265, No. 5172, pp.669-671, ISSN 0036-8075

Warf, M.B.; Nakamori, M.; Matthys, C.M.; Thornton, C.A.; \& Berglund, J.A.; (2009). Pentamidine reverses the splicing defects associated with myotonic dystrophy. Proceedings of National Academy of Sciences of United States of America, Vol.106, No.44, pp.18551-18556, ISSN 0027-8424

Warf, M.B. \& Berglund, J.A. (2010). Role of RNA structure in regulating pre-mRNA splicing. Trends Biochemical Science. Vol.35, No.3, pp.169-178, ISSN 0968-0004

Warner, J.P.; Barron, L.H.; Goudie, D.; Kelly, K.; Dow, D.; Fitzpatrick, D.R.; \& Brock, D.J. (1996). A general method for the detection of large CAG repeat expansions by fluorescent PCR. Journal of Medical Genetics, Vol.33, pp.1022-1026, ISSN 0022-2593

Wheeler, T.M.; Lueck, J.D., Swanson, M.S.; Dirksen, R.T.; \& Thornton, C.A. (2007). Correction of $\mathrm{ClC}-1$ splicing eliminates chloride channelopathy and myotonia in mouse models of myotonic dystrophy. The Journal Clinical Investigation. Vol.117, No.12, pp. 3952-3957, ISSN 0021-9738

Wheeler, T.M.; Sobczak K.; Lueck, J.D.; Osborne, R.; Lin, X.; Dirksen, R.T.; \& Thornton, C.A. (2009). Reversal of RNA dominance by displacement of protein sequestered on triplet repeat RNA. Science 325(5938):336-339, ISSN 0036-8075

Winblad, S.; Lindberg, C.; \& Hansen, S.(2006). Cognitive deficits and CTG repeat expansion size in classical myotonic dystrophy type 1 (DM1). Behavioral and Brain Functions, Vol. 2, pp.16. ISSN 1744-9081

Wojciechowska, M.; Bacolla, A.; Larson, J.E.; \& Wells, R.D. (2005), The myotonic dystrophy type 1 triplet repeat sequence induces gross deletions and inversions. Journal of Biological Chemistry. Vol.280, No.2, pp.941-952, ISSN 0021-9258

Zerylnick, C.A.; Torroni, A.; Sherman, S.L.; \& Warren, S.T.(1995). Normal variation at the myotonic dystrophy locus in global human populations. American Journal of Human Genetics. Vol.56, pp.123-130, ISSN 0002-9297 


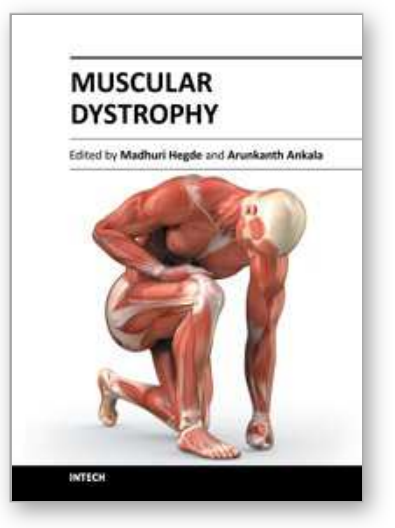

\author{
Muscular Dystrophy \\ Edited by Dr. Madhuri Hegde
}

ISBN 978-953-51-0603-6

Hard cover, 544 pages

Publisher InTech

Published online 09, May, 2012

Published in print edition May, 2012

With more than 30 different types and subtypes known and many more yet to be classified and characterized, muscular dystrophy is a highly heterogeneous group of inherited neuromuscular disorders. This book provides a comprehensive overview of the various types of muscular dystrophies, genes associated with each subtype, disease diagnosis, management as well as available treatment options. Though each different type and subtype of muscular dystrophy is associated with a different causative gene, the majority of them have overlapping clinical presentations, making molecular diagnosis inevitable for both disease diagnosis as well as patient management. This book discusses the currently available diagnostic approaches that have revolutionized clinical research. Pathophysiology of the different muscular dystrophies, multifaceted functions of the involved genes as well as efforts towards diagnosis and effective patient management, are also discussed. Adding value to the book are the included reports on ongoing studies that show a promise for future therapeutic strategies.

\title{
How to reference
}

In order to correctly reference this scholarly work, feel free to copy and paste the following:

Jonathan J. Magaña and Bulmaro Cisneros (2012). Myotonic Dystrophy Type 1 (DM1): From the Genetics to Molecular Mechanisms, Muscular Dystrophy, Dr. Madhuri Hegde (Ed.), ISBN: 978-953-51-0603-6, InTech, Available from: http://www.intechopen.com/books/muscular-dystrophy/myotonic-dystrophy-type-1-dm1-fromthe-genetics-to-molecular-mechanisms

\section{INTECH}

open science | open minds

\section{InTech Europe}

University Campus STeP Ri

Slavka Krautzeka 83/A

51000 Rijeka, Croatia

Phone: +385 (51) 770447

Fax: +385 (51) 686166

www.intechopen.com

\section{InTech China}

Unit 405, Office Block, Hotel Equatorial Shanghai

No.65, Yan An Road (West), Shanghai, 200040, China

中国上海市延安西路65号上海国际贵都大饭店办公楼 405 单元

Phone: +86-21-62489820

Fax: $+86-21-62489821$ 
(C) 2012 The Author(s). Licensee IntechOpen. This is an open access article distributed under the terms of the Creative Commons Attribution 3.0 License, which permits unrestricted use, distribution, and reproduction in any medium, provided the original work is properly cited. 